\title{
Belarus's National Narratives and Representation of the Grand Duchy of Lithuania
}

Jevgenijs Rjascenko

West Virginia University

Follow this and additional works at: https://researchrepository.wvu.edu/etd

\section{Recommended Citation}

Rjascenko, Jevgenijs, "Belarus's National Narratives and Representation of the Grand Duchy of Lithuania" (2014). Graduate Theses, Dissertations, and Problem Reports. 416.

https://researchrepository.wvu.edu/etd/416

This Thesis is protected by copyright and/or related rights. It has been brought to you by the The Research Repository @ WVU with permission from the rights-holder(s). You are free to use this Thesis in any way that is permitted by the copyright and related rights legislation that applies to your use. For other uses you must obtain permission from the rights-holder(s) directly, unless additional rights are indicated by a Creative Commons license in the record and/ or on the work itself. This Thesis has been accepted for inclusion in WVU Graduate Theses, Dissertations, and Problem Reports collection by an authorized administrator of The Research Repository @ WVU. For more information, please contact researchrepository@mail.wvu.edu. 


\title{
Belarus's National Narratives and Representation of the Grand Duchy of Lithuania
}

\author{
Jevgēnijs Rjaščenko \\ Thesis submitted to the \\ Eberly College of Arts and Sciences \\ at West Virginia University \\ in partial fulfillment of the requirements \\ for the degree of \\ Master of Arts in \\ History
}

\author{
Robert Blobaum, Ph.D., Chair \\ Katherine Aaslestad, Ph.D. \\ Joshua Arthurs, Ph.D. \\ Department of History
}

Morgantown, West Virginia
2014

Keywords: Belarus, nation-building, history textbooks, Grand Duchy of Lithuania, national narratives. 


\section{ABSTRACT \\ Belarus's National Narratives and Representation of the Grand Duchy of Lithuania}

\section{Jevgēnijs Rjaščenko}

In its theoretical framework this thesis relies on the discussion of the existing approaches towards the study of nationalism such as the perennialist, the modernist/constructivist and the ethno-symbolist. The ethno-symbolist approach by Anthony D. Smith, however, is chosen as the most appropriate for examining Belarus's nation-building process and therefore, its ability to explain different expressions of Belarus's national narratives is emphasized. The empirical discussion of Belarus's post-independence nation-building process explains the peculiarity of the Belarusian case in which the official national narrative coexists with the alternative national narrative in Belarus's public sphere. The research question, however, is centered on the problem of the Belarus's national narrative - as it is outlined in Belarus's history textbooks - and its representation of Lithuania with regard to the medieval past of the Grand Duchy of Lithuania, which is shared by the both modern republics of Belarus and Lithuania.

With the analysis of Belarus's national narratives and history textbooks as a case study, the thesis responds to concerns of some Lithuanian historians and answers the question whether Belarus's national narrative and the representation of Lithuania presented in the textbooks are contesting and "rewriting" the Lithuanian past, particularly in terms of Lithuanian input in the creation and maintenance of the Grand Duchy from the mid-thirteenth century until the late eighteenth century. The aforementioned research provides an unprecedented analysis of Belarus's history textbooks in regard to their representation of another national group during the particular period of a shared medieval past. 


\section{ACKNOWLEDGMENT}

This Master's thesis is the final product of a combination of particular people and circumstances that have supported me throughout the process of writing and graduating from both the University of Tartu and the West Virginia University. Therefore, I want to thank Dr. Heiko Pääbo and Prof. Robert Blobaum for their support, advice and professional ability to run the marvelous Atlantis program that has united so many people across the Atlantic. On the Estonian side, I want to thank my supervisor Prof. Andres Kasekamp for his thorough comments and for being with me from the very start in shaping the form of my future thesis. On the American side, I want to thank Prof. Katherine Aaslestad and Prof. Joshua Arthurs for their professionalism, wonderful classes and ability to show the way through the myriad of information on nationalism and dozens of pages of our own work. In addition, I most certainly wish to thank my family for the trust they have placed in me and for their support in my academic and non-academic endeavors. I am also grateful for the love of my old friends who have waited for me, and the new ones whom I have found during my studies overseas. 


\section{TABLE OF CONTENTS}

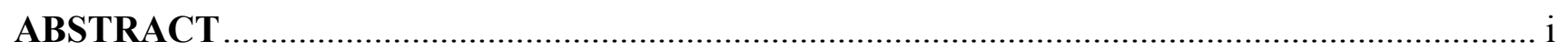

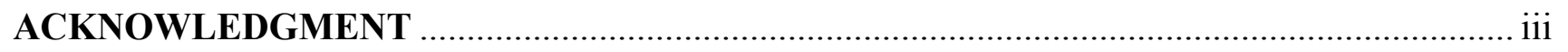

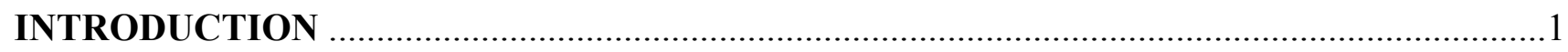

CHAPTER ONE: THE THEORETICAL FRAMEWORK …….................................................

Ethno-Symbolism and Belarusian National Narratives ............................................................18

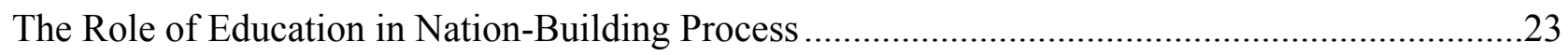

Political Memory as a Part of Collective Memory ……..................................................................26

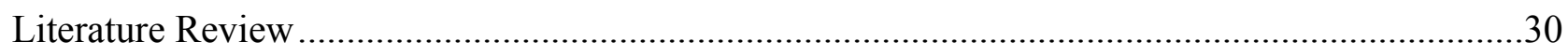

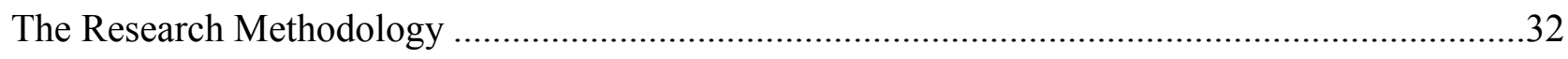

CHAPTER TWO: UNDERSTANDING BELARUSIAN NATIONALISM.......................................38

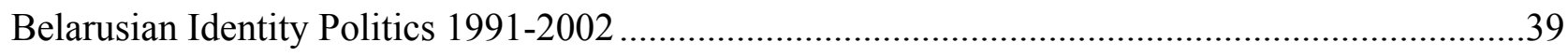

Belarusian Identity Discourse 2002 - present.....................................................................5

CHAPTER THREE: CONTESTED HISTORY AND MEMORY IN BELARUSIAN HISTORY

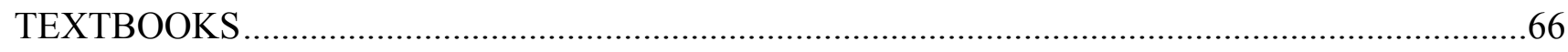

The Belarusian National Narrative in Legal Documents ................................................................67

Existing Research on Belarusian History Textbooks ...................................................................70

Construction of the Official Belarusian National Narrative in Belarusian History

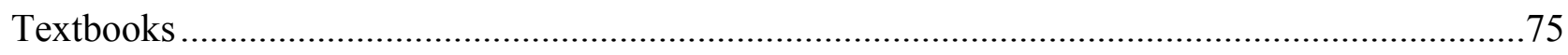

Representation of Lithuania within the Grand Duchy of Lithuania in Belarusian History

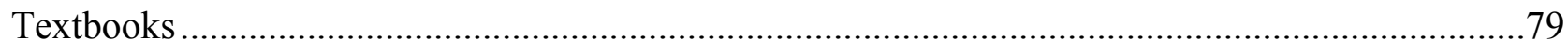

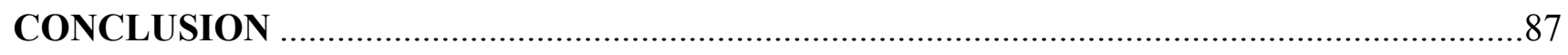

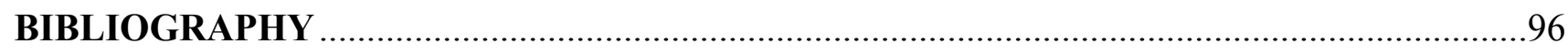




\section{INTRODUCTION}

"The time has come to distinguish what will become the unifying idea for all citizens of Belarus - from an academic to a peasant. Of course, the base of it is patriotism, readiness to protect our heritage. These feelings are not transmitted on genetic level, but have to be molded through the interest in history, [and] culture of our nation.",

Alyaksandr Lukashenka, President of the Republic of Belarus, Speech during the special Presidential Award "For Spiritual revival" January 9, 2014

On September 17, 2002 during an interview regarding Belarusian culture in the age of globalization, Alyaksandr Lukashenka asserted that it was necessary to adjust to the modern age by developing a national idea: "I would be happy if during my "presidential life" such an idea would be formulated." $\mathrm{He}$ was doubtful, however, whether such an idea could be defined due to the overall discouraging condition of Belarusian society under which, according to Lukashenka, it could be "(...) very hard to come up with it."

More than ten years later, on January 9, 2014 President Lukashenka presented a speech emphasizing, among other things, the necessity to “(...) distinguish what will become the unifying idea for all citizens of Belarus (...)"3 Even though it is too early to generalize about the outcome of this speech, it nevertheless marked either the inception of a new process or the climax of another. It is more than possible that the speech was a hint to the Belarusian cultural and political elite, as well as state

\footnotetext{
${ }^{1}$ Alyaksandr Lukashenka's speech during the special Presidential Award "For Spiritual Revival, Minsk, January 9, 2014, President of the Republic of Belarus http://president.gov.by/ru/news ru/view/aleksandr-lukashenko-prinjal-uchastie-vtseremonii-vruchenija-premii-za-duxovnoe-vozrozhdenie-i-spetspremij-7789/

${ }^{2}$ From the record of Alyaksandr Lukashenka's Press Conference held on September 17, 2002, news agency www.tut.by. Стенограмма пресс-конференции Президента Республики Беларусь А.Г.Лукашенко 17 сентября 2002г. Available http://news.tut.by/society/18153.html

${ }^{3}$ Alyaksandr Lukashenka's speech during the special Presidential Award "For Spiritual Revival, Minsk, January 9, 2014, President of the Republic of Belarus http://president.gov.by/ru/news ru/view/aleksandr-lukashenko-prinjal-uchastie-vtseremonii-vruchenija-premii-za-duxovnoe-vozrozhdenie-i-spetspremij-7789/
} 
officials, that Belarus needs a national idea or a unifying element for all people of Belarus “(...) from an academic to a peasant. ${ }^{, 4}$ On the other hand, the speech might have marked the climax of the period initiated in 2002 in which Lukashenka mentioned the prospective development of a national idea.

The first steps in formulating the national idea were taken already in 2003 when the Belarusian government accepted a policy document from the Ministry of Education "On Ideological Guidance of Educational Work" that called for a series of plans that reemphasized Belarus culture, history and the idea of patriotism. Several criteria were mentioned that had to be cultivated among pupils and students, such as a world view reflecting the ideals of Belarusian state and society, respect for national culture, respect for the traditions of other people and nationalities, as well as the development of key personal characteristics such as moral character, civic consciousness, patriotism, collectivism and diligence. ${ }^{5}$ Thus, the Belarusian state on the official level ensured that such characteristics as patriotism, civic consciousness and dignity would be promoted through state education. It meant that the state's ideological foundation would be expressed and promoted by the teaching staff and, more importantly, through official textbooks.

In 2004, the "National Strategy of Stable Social-Economic Development of the Republic of Belarus until 2020" stated that "ideological work, introduced to national consciousness via education and enlightenment should transmit the ideas and principles of stable development to every citizen." Later, on November 4, 2006 the Council of Ministers of the Republic of Belarus accepted the "General vectors of social-economic development of the Republic of Belarus for 2006-2015" wherein Article Three stated that the priorities of social-economic development included education, culture, healthcare,

\footnotetext{
${ }^{4}$ Alyaksandr Lukashenka's speech during the special Presidential Award "For Spiritual Revival, Minsk, January 9, 2014, President of the Republic of Belarus http://president.gov.by/ru/news ru/view/aleksandr-lukashenko-prinjal-uchastie-vtseremonii-vruchenija-premii-za-duxovnoe-vozrozhdenie-i-spetspremij-7789/

${ }^{5}$ Приказ Министерства образования Республики Беларусь от 16.12.2003 N 497 “Об идеологическом сопровождении воспитательной работы".

${ }^{6}$ Национальная комиссия по устойчивому развитию Республики Беларусь. Национальная стратегия устойчивого сочиально-экономического развития Республики Беларусь на период до 2020 г. (Минск: Юкипак, 2004), 14.
} 
housing, as well as branches formulating and improving the quality of human capital. ${ }^{7}$ This document shows that the Belarusian state exercises a common practice of nation-states in which the educational system is used as a channel to introduce and transmit national values and ideas. Thus, the information presented in school textbooks should possess certain ideological values to nurture civic consciousness such as patriotism, vigor, etc. An analysis of Belarusian history textbooks presents a case study for this research of Belarus's national narratives and their representation in the Belarus's public space.

In this study, the national idea is understood as a unifying national narrative on the development of "Belarusianness" throughout Belarusian history that would nurture the population's national consciousness, patriotism, and sense of belonging to the modern Belarusian state. This process, however, represents a challenge to Belarus because the state's official national narrative and understanding of its history are contested by various other actors, including non-governmental groups (NGOs) and the political opposition, which itself provides alternative interpretations of "Belarusianness." Existing research on Belarusian nation-building tends to distinguish several models of Belarusian nationalism. For example, Grigory Ioffe distinguishes three models - Nativist, proRussian and Creole. ${ }^{9}$ Even though researchers assign different names to such models, in general terms they are distinguished on the basis of official and alternative approaches to the Belarusian nationbuilding process.

Nativist, European, Westernizer or other alternative approaches to the Belarusian national narrative stand in opposition to the official pro-Russian, pro-Soviet national narrative because they see the origins of Belarusian nationhood stemming from the medieval period, claiming that Belarusian

\footnotetext{
7 Pravo.by Национальный правовой интернет-портал Республики Беларусь, Постановление Совета Министров $\begin{array}{lllllll}\text { Республики } & \text { Беларусь } & 4 & \text { ноября } & 2006 & \text { г. } & \text { № }\end{array}$ http://www.pravo.by/main.aspx?guid $=3871 \& \mathrm{p} 0=\mathrm{C} 20601475 \& \mathrm{p} 2=\{\mathrm{NRPA}\}$

${ }^{8}$ See, for example, Nicholas Vakar, Belorussia: The Making of A Nation (Cambridge: Harward University Press, 1956), Nelly Bekus, Struggle Over Identity. The Official and the Alternative "Belarusianness" (Budapest: Central European University Press, 2010). Available: http://books.openedition.org/ceup/581 or Grigory Ioffe, "Understanding Belarus: Belarusian Identity" Europe-Asia Studies, Vol. 55, No. 8 (December, 2003).

${ }^{9}$ Grigory Ioffe, "Culture Wars, Soul-Searching, and Belarusian Identity" East European Politics and Societies, 21, 2 (2007).
} 
nationhood developed during the Grand Duchy of Lithuania. The pro-Russian narrative, on the other hand, claims that Soviet Belarus was the foremost among Belarusian nation-building projects and only under the Soviet rule could Belarus develop its unique nationhood. ${ }^{10}$ One of the distinctions between the two approaches is in their visions of the territorial borders of Belarus. Alternative narratives see Belarusian territory larger than it is nowadays due to the expanse of historical Belarusian lands within the Grand Duchy of Lithuania.

The official national narrative of Belarus, as was mentioned above, is therefore presented in Belarusian history textbooks. The official narrative, however, does not necessarily present simply a proRussian model any longer since the process of Belarusian nation-building has become more complicated after 2002 when President Lukashenka's project of unification with Russia failed. ${ }^{11}$ It is necessary to emphasize that the official national narrative tries to promote a nation-building policy that would be broader and more complicated than a simple focus on the Soviet and Slavic origins of Belarus and Belarusians. The official narrative of Belarusian nationalism, as presented in history textbooks, has to maneuver between the pro-Russian and Nativist models to produce its own narrative, one that was described as "Creole" by Grigory Ioffe.

In this study the history of the Grand Duchy of Lithuania is extremely important because it is a period where inceptions of a Belarusian statehood can be seen. The question is, however, how "Belarusianness" will be compared to its treatment of other regional nationalities especially the Lithuanians, since both of them ruled the Grand Duchy. The Lithuanian case was chosen for this research and not, for example, the Polish one because Lithuania shares a common past with Belarus in an early common state that they ruled together before 1569 . It provides a place for new interpretations of evidence and events that happened during that period which is considered a "glorious" time for

\footnotetext{
${ }^{10}$ Andrew Savchenko, Belarus - A Perpetual Borderland (Leiden, Boston: Brill, 2009), 228.

${ }^{11}$ Andrew Wilson, Belarus: the Last Dictatorship in Europe (New Haven, London: Yale University Press, 2011), 200.
} 
Lithuania and "glorious" for Belarus in its alternative national narrative. It seems that starting in 2002 the question of national narrative and its importance in Belarus nation-building started to be infused with new interpretations. Moreover, these new interpretations started to affect the shared past with Lithuania and the Lithuanian national narrative itself.

A national idea should be based on national values, but these national values should be grounded in something that a country is proud of - its distinct historical past. ${ }^{12}$ In many cases national history appears to be important for establishing certain narratives that would develop patriotism and pride among the citizens of that country. In this regard, historical textbooks, as government publications, appear to be a reliable source in an attempt to find the foundations upon which the state's version of the national idea is based.

A distinct historical past, in the case of Belarus, refers to the times when Belarusian lands were part of the Grand Duchy of Lithuania and had directly contributed to the existence of the Duchy. In the thirteenth century the king of Lithuania Mindaugas (in Belarusian - Міндогz) expanded his territory and acquired the lands that today embrace modern Belarus. This period is considered to be the creation of the Grand Duchy of Lithuania and was accomplished through voluntary arrangements between Lithuanians and Belarusians such as marriages, trade and centuries-long cohabitation. ${ }^{13}$ This period, however, appears to be contested by some scholars since it has been targeted for nation-building purposes in Lithuania as well as in Belarus.

In September 2013 Professor Valdas Rakutis from the General Jonas Žemaitis Lithuanian Military Academy expressed a concern that:

For thirty years now starting from school, most Belarusians are taught that Mindaugas, Gediminas and all the others were Belarus leaders and that the country was Belarus. And

\footnotetext{
${ }^{12}$ Yael Zerubavel, "The Historic, the Legendary, and the Incredible: Invented Tradition and Collective Memory in Israel" in Commemorations: the Politics of National Identity, edited by John Gillis, (Princeton: Princeton University Press, 1994$), 107$.

${ }^{13}$ Jan Zaprudnik, Belarus: At a Crossroads of History (Westview Press, 1993), 19.
} 
that the Samogitians are some vague bunch of people living in the west and who are somehow different but their significance in this country isn't expressly indicated. And all that happened here happened with the hard work of the Litvinians - as they call themselves - Belarusians. ${ }^{14}$

According to Rakutis, this clearly indicates that Belarusian textbooks and the emerging Belarusian national narrative challenged the Lithuanian national narrative since Belarusians seem to downplay Lithuanians' historical importance in the establishment of the Grand Duchy of Lithuania as well as in their shared past. Thus, certain concerns exist that Belarusian history textbooks "rewrite" the Lithuanian past.

The theoretical framework of this research is based on the discussion of nationalism studies and the work of its leading proponents. For this research, the role of education in the nation-building process is vital and will be discussed as part of the theoretical framework. The models developed by Andy Green and Abigail Green on the role of education in the nation-building process are discussed in particular in this research.

The initial aim of this research is to ask broader conceptual questions and understand the Belarusian nation-building process in order to place the case study on Belarusian history textbooks in a broader discussion of the official and the alternative national narratives that are visible in the Belarus's public space. For the purposes of the case study, this research looks at mainly seventh and eighth-grade history textbooks to analyse the representation of Lithuanians and Belarusians in the narratives presented in Belarusian history textbooks. This choice of textbooks is based on the existing research of a Belarusian scholar who analysed Belarusian history textbooks from the 1990s to 2009 in order to examine their representation of the historical past. Tatyana Ostrovskaya concluded that textbooks of

\footnotetext{
${ }^{14}$ The Lithuanian Tribune, News and Views from Lithuania, "Belarusian rewriting history - do you think you're the Lithuanians?" September 27, 2013, available: http://www.lithuaniatribune.com/52087/belarusians-rewriting-history-do-youthink-youre-the-lithuanians-201352087/
} 
fifth and sixth grades, as well as tenth and eleventh grades do not focus on the topic of the formation of Belarusian nationhood. ${ }^{15}$ Furthermore, one sixth-grade textbook was reviewed by the author of this thesis and it was thereby determined that at this grade level the periodization of the textbook does not include the Grand Duchy of Lithuania, while textbooks designed for the tenth and eleventh grades focus primarily on modern history.

After reaching conclusions on the representation of Belarusian and Lithuanian national roles in Belarusian history textbooks, it will be possible to uncover how the construction of the Belarusian national narrative changes depictions of the Belarusian political role in the region and more precisely Belarusians historical ties to the Republic of Lithuania. Moreover, how does the Belarusian national narrative as developed in history textbooks challenge the Lithuanian historical narrative?

The research represents a social science approach to modern nationalism and to the construction of national histories. Therefore, the following hypotheses are formulated:

H1: The Belarusian national narrative in history textbooks does not challenge the Lithuanian national narrative, but seeks to highlight and empower the "Belarusianness" of their shared past for the nation-building purposes.

H2: The more the official Belarusian narrative tries to establish a Belarusian national idea, the more it resembles the alternative narrative of Belarusian opposition.

The value of an empirical study of Belarusian-Lithuanian representation in Belarusian history textbooks is that it is able to produce relevant evidence for an understanding of the Belarusian national narrative and for the nation-building process in general. Furthermore, this research is able to conceptualize the existing national narratives that are supported by various actors within the Belarus's public space. In addition, it produces greater understanding of practical applications of the theoretical

15 Татьяна Островская, Генеология Исторической Памяти Белорусов в Контексте Образовательных Практик (Genealogy of Historical Memory of Belarusian in Context of Education Practices) Belarusian Institute for Strategic Studies, SA \#1/2010RU, (October 20, 2010), 33. 
framework of nationalism. Besides that, responding to concerns of some Lithuanian scholars, the study addresses a concrete problem whether the Belarusian national narrative tries to "rewrite" the Lithuanian past.

Chapter One presents the broader theoretical framework for this research based on the discussion of nationalism theory and the ethno-symbolist approach of Anthony D. Smith in particular. Chapter Two provides an empirical analysis of different expressions of the Belarusian national narrative as well as their essence as presented in official and alternative discourses. Chapter Three presents the empirical analysis of Belarusian history textbooks with regard to the period of the Grand Duchy of Lithuania, primarily focusing on expressions of the Belarusian and the Lithuanian presence in the textbooks. This analysis also relies on existing studies of Belarusian history textbooks, which are relevant for the purposes of periodization and support of certain arguments.

The research methodology of my study lies in the interpretive approaches to narrative analysis. Since the role of Lithuania and Lithuanians is not the primary focus of Belarusian history textbooks, particular attention is paid to their every mention in the textbooks. Furthermore, history textbook analysis is supplemented by an analysis of the political discourse of the Belarusian national narrative, among supporters of the official national narrative of Belarus as well as among supporters of the alternative national narratives. Moreover, the study focuses on symbols of Belarusian collective identity that are visible in the public sphere and which facilitate creation of collective memory among Belarusians. Such symbols are movies, music, monuments, language politics, reenactment groups, etc.

Studies that are concerned with analysis of history textbooks might face similar challenges due to the peculiar relationship between the government and history-textbook publishing and distribution. In the case of Belarusian textbooks it was problematic to acquire older textbooks, which would expand the scope of this study. In this regard, this study is forced to focus on the limited number of the most recent 
history textbooks as well as on the existing analysis of previous Belarusian history textbooks conducted by other scholars. The author understands the challenge of possible bias that might be connected with this previous research; however, I attempt to use relevant observations from this work as objectively as possible. Therefore, the analysis of history textbooks is supplemented with the analysis of various speeches and political statements, as well as analysis of existing symbols, that would emphasize one or another form of "Belarusianness" in the Belarusian public sphere. 


\section{CHAPTER ONE: THE THEORETICAL FRAMEWORK}

Hayden White in his work The Historical Text as Literary Artifact provides a broader understanding of a historian's work and the meaning of historical narrative as an outcome of a historian's work. White argues that "historical narratives (...) are verbal fictions, the contents of which are as much invented as found and the forms of which have more in common with their counterparts in literature than they have with those in the sciences." "16 Earlier, Robin Collingwood claimed that historians, by interpreting the evidence, are inventing historical narratives where a historian's constructive and historical imagination was necessary. ${ }^{17}$ Moreover, this imagination is structural rather than ornamental which points to the importance of imagination in constructing a structure of historical narratives. In fact, history only reveals itself through the production of specific narratives where "historical imagination" is used in the very process of production. ${ }^{18}$

Another function of "historical imagination" is that it enables historians to establish connections between items of evidence. ${ }^{19}$ Furthermore, without the historical imagination "the historian would have no narrative to adorn." ${ }^{20}$ Since historians are using "raw" sources, i.e. data, documents and texts, it is necessary to interpret them by choosing a certain type of story as well as methodology in order to structure the events and processes that occurred in history. ${ }^{21}$ Furthermore, Hayden White concludes that we can only know the actual (history) by contrasting it with or likening it to the imaginable (fiction). ${ }^{22}$ All of the aforementioned supports the idea that there can be several national narratives that are

\footnotetext{
${ }^{16}$ Hayden White, “The Historical Text as Literary Artifact” Tropics of Discourse (1978): 82.

${ }^{17}$ Robin Collingwood, The Idea of History, edited by Jan Van der Dussen (New York: Oxford University Press, 2005), 9-10.

${ }^{18}$ Michel-Rolph Trouillot, Silencing the Past: Power and the Production of History (Boston: Beacon Press, 1995$), 25$.

19 Marine Hughes-Warrington, "How Good an Historian Shall I Be?" R.G. Collingwood, the Historical Imagination and Education, British Idealist Studies Series 2: Collingwood, Volume 2 (Bedfordshire: Andrews UK, 2003 ): 170.

${ }^{20}$ Roger G. Collingwood, The Historical Imagination, An Inaugural Lecture delivered before the University of Oxford on 28 October 1935 (Oxford: The Clarendon Press, 1935), 13.

${ }^{21}$ White, 88.

22 Ibid, 98.
} 
dependent on the interpretation of the sets of events and processes that occurred in the past because the historical problem or narrative is settled in the past only until someone else decides to reopen it. ${ }^{23}$

Eventually, narrative construction or story-telling is the most important function of writing history. ${ }^{24}$ Therefore, several types of narratives might be distinguished. According to Allan Megill's categorization, a micro-narrative focuses on a particular event from the past; a master narrative seeks to explain a broader segment of history like a particular period; a grand narrative "is an account that purports to be the authoritative account of history in general" ${ }^{, 25}$; and a metanarrative draws upon a particular cosmology or metaphysical foundation such as Christianity. ${ }^{26}$ The history of the Grand Duchy of Lithuania, as a part of Belarusian history, can be considered a master narrative since it is a broader segment or period of history. This period to a certain extent is also used in the nation-building discourse in Belarus since it is an example of the glorious past where inceptions of "Belarusianness" can be claimed. Moreover, both the official and the alternative national narratives in Belarus use this past but employ different interpretations. In this case, the national narrative that can also be termed the grand narrative within my research, consists of different events and processes from the past that are supposed to have national importance for the creation of an independent Belarusian nation and Belarusian consciousness among the people. Official and alternative discourses on the inceptions of Belarusian consciousness and statehood differ in various significant points that will be analyzed in this research.

In broader discussions of nation and nationalism, it is possible to distinguish between two main schools of thought - the modernist or the constructivist that sees the nation as a modern construct - and the perennialist school, which sees the nation as an ancient entity that naturally developed through the

\footnotetext{
${ }^{23}$ Collingwood, The Ideas of History, 16.

${ }^{24}$ Anna Green and Kathleen Troup, The Houses of History: A Critical Reader in Twentieth-century History and Theory (Manchester: Manchester University Press, 1999), 204.

${ }^{25}$ Allan Megill, Historical Knowledge, Historical Error: A Contemporary Guide to Practice, with contributions by Steven Shepard and Phillip Honenberg (London: The University of Chicago Press, 2007), 67.

${ }^{26}$ Green and Troup, 204.
} 
time and space. Despite the existence of large amount of theoretical and philosophical literature on nationalism, one of the paradoxes of the international discussion about nation and nationalism is the failure to produce a uniform and generally accepted terminology of these concepts. ${ }^{27}$ In this regard the concepts of nation and nationalism have to be discussed separately and according to each school of thought.

The modernist school of thought represents the dominant orthodoxy in nationalism studies and therefore, the modernity of nations is sometimes assumed unintentionally. The leading representative of the modernist school of thinking, Benedict Anderson, understands the nation as "an imagined political community - and imagined as both inherently limited and sovereign." 28 According to Anderson, the nation is constructed and does not really have ethnic or historical roots that would define its present conditions. The perennialist school of thought, on the other hand, offers another perspective according to which nations have existed from time immemorial and therefore cannot be defined by the age of modernity. Even though the perennialist school recognizes that nationalist ideology is a contemporary phenomenon, it mainly stresses the idea of social evolution, gradualism, progress and social and cultural accumulation. $^{29}$ One of the most important distinctions between the two schools is in the formulation of "national ontology" - a question - whether a nation is an existing phenomenon in social reality or is an "imagined" or constructed phenomenon. ${ }^{30}$

Starting with the nineteenth century until the mid-twentieth century, the perennialist approach had been largely shared by scholars. After the Second World War, however, when the connection between such concepts as "race" and "nation" started to be questioned, its overall acceptability declined.

\footnotetext{
${ }^{27}$ Miroslav Hroch, Social Preconditions of National Revival: A Comparative Analysis of the Social Composition of Patriotic Groups among the Smaller European Nations (Cambridge University Press, 1985), 192.

${ }^{28}$ Benedict Anderson, Imagined Communities: Reflections on the Origin and Spread of Nationalism (London: Verson, 1983), 6.

${ }^{29}$ Anthony D. Smith, Nationalism: Theory, Ideology, History (Polity, 2001), 49.

${ }^{30}$ Nelly Bekus, Struggle Over Identity: The Official and the Alternative "Belarusianness" (Budapest: Central European University Press, 2010), 15. Available: http://books.openedition.org/ceup/581
} 
Perennialism tries to see historical continuity in the relationship between ethnicity and nationalism. In fact, the approach itself is more about ethnicity and ethnic identity rather than nationalism and nations in particular. Ethnic groups for perennialism are strictly historical and social, rather than natural. ${ }^{31}$ Therefore, this approach should not be confused with the naturalist conception of the nation that is the basis for the "primordialist" approach. ${ }^{32}$ It is important to note that the perennialist approach refuses to see ethnic communities as given in nature, but rather as human and social phenomenon that have existed throughout history and eventually made them immemorial to the members of those communities. This approach, however, emphasizes the linear development of a nation that is always undergoing a process of gradual development while keeping the ethnic constituent of a nation largely intact.

According to this school of thought, ethnicity can be regarded as a "tangible" reality that links human beings from generation to generation. ${ }^{33}$ First and foremost, the biological component of ethnicity makes it "tangible," however; the approach goes beyond simple biological connections between people. Therefore, ethnicity is not something that is engraved in a rock on biological level and therefore cannot be changed. In fact, the very idea of the ethnicity is to be preserved throughout the process of its historical change. Thus, it is clear that the nation, according to the perennialist school of thought, is a historical and social phenomenon that developed throughout history due to close interrelation of people within certain ethnic communities. Within this approach, the modernity of nations is rejected, but the modernity of nationalism as a political movement is recognized. Nevertheless, the nation is considered a genuine historical product of social coexistence of particular ethnic communities rather than a product of the modern age.

\footnotetext{
${ }^{31}$ Anthony D. Smith, Nationalism and Modernism: a Critical Survey of Recent Theories of Nations and Nationalism (London, New York: Routledge, 1998), 159.

${ }^{32}$ Smith, Nationalism: Theory, 50.

${ }^{33}$ Smith, Nationalism and Modernism, 160.
} 
With the stress on historical past of ethnic communities, the question arises whether this approach can be applicable to the Belarusian nation whose past appears to be contested by several national narratives that disagree on the ethnic component of the Belarusian nation. In general, this approach devotes less attention explaining the concept of civic as well as cultural identity of a nation in comparison to its ethnic components. The idea of a civic nation, however, seems applicable to the present state of Belarus's official nation-building process in which Belarusian ethnicity and its historical transformations are emphasized less than the idea of people's belonging to the modern Belarusian state. Furthermore, the perennialist approach fails to see the important difference between the pre-modern and modern ethnic communities, and it overlooks the importance of cultural components and complexity if human association. ${ }^{34}$ In this regard, it is questionable whether the perennialist approach is able to theoretically contribute to a discussion on the Belarusian nation and therefore, the modernist approach should be elaborated.

One of the most prominent representatives of the modernist school of thought, as already noted, is Benedict Anderson who understands nationalism as the concept associated with "kinship" and "religion," rather than with more ideological narratives as "liberalism" or "fascism." 35 He sees nationalism as a cultural artifact of a particular kind, which is capable of being transplanted to a variety of social terrains, and merged with political and ideological constellations. Thus, nationalism is not an ideology but rather an imagined collective consciousness that exists within a society or a group of people who think about themselves as related to one another. ${ }^{36}$ This is why concepts of "kinship" and "religion" contribute as comparisons to nationalism since they also prescribe certain imagined criteria or cultural systems to be associated with other people of their kind, i.e. Orthodox, Muslims etc.

\footnotetext{
${ }^{34}$ Anthony D. Smith, Nations and Nationalism in Global Era (Polity Press, 1995), 54.

${ }^{35}$ Anderson, 5.

${ }^{36}$ Ibid, 4.
} 
Anderson claims that the nation is " $(\ldots)$ an imagined political community - and imagined as both inherently limited and sovereign., ${ }^{37}$ The nation becomes imagined because people of a particular society or community will never know each other personally; therefore, they are compelled to imagine their sameness and collectivity. Later, this imagined sameness gives way to a political community whose goal is a separate nation of the people of their kind. The imagined sameness, however, is limited because it stretches only to the boundaries where another nation is imagined in a similar way. ${ }^{38}$ According to Anderson, awareness of national identity is facilitated by "print-capitalism" - the production of books in a certain language or vernacular that would point to the existence of other members of particular linguistic group. More precisely, “(...) print-capitalism made it possible for rapidly growing numbers of people to think about themselves, and to relate themselves to others, in a profoundly new way."39 Through these steps of self-imagining a nation can be invented and a nation-state constructed.

Another modernist, Ernest Gellner claims: "Nations are not inscribed into the nature of things (...). Nor were the national states the manifest ultimate destiny of ethnic or cultural groups. ${ }^{40}$ According to Gellner, nations did not develop through time with certain ethnic backgrounds as the perennialist school claims. Therefore, nations did not really exist since cultural groups existed that would overlap and intertwine and sometimes have certain political units of all shapes and sizes. ${ }^{41}$ What is important in Gellner's approach, however, is the assumption that nationalism in such cultural groups engenders nations and not vice versa. ${ }^{42}$

Gellner does not contradict the assumption that cultural groups existed throughout history; however, he believes that "nation can be defined only in terms of the age of nationalism."43 Therefore,

\footnotetext{
${ }^{37}$ Ibid, 6.

${ }^{38}$ Ibid, 7.

${ }^{39}$ Ibid, 36.

${ }^{40}$ Ernest Gellner, Nations and Nationalism (Ithaca, London: Cornell University Press, 1983), 49.

41 Ibid, 49.

${ }^{42}$ Ibid, 51 .

${ }^{43}$ Ibid, 55.
} 
culture has always existed among groups of people, but the only difference is that they were not able to unite in a nation because they did not have particular knowledge or necessity to do so. Accordingly, when the realization of sameness came in the age of nationalism - facilitated by external factors like print-capitalism - it was possible to develop nationalism, which facilitated the establishment of nations. In this regard, national sameness is not the product of ethnicity or cultural development but rather the product of fusion of will, culture, and polity at a particular point in time. ${ }^{44}$

Not only can a nation be invented, but also various traditions that would emphasize a particular nation's historical continuity with modern political formations. Eric Hobsbawm in his work Inventing Traditions claims that traditions, which claim to be old, are often recent in origin are sometimes invented. ${ }^{45}$ Such invention is done to support the idea of historical continuity with a certain greater past that would legitimize community's presence in a particular time and space. In line with this idea the great nineteenth-century French historian Ernest Renan claimed: "To have common glories in the past and to have common will in the present; to have performed great deeds together, to wish to perform still more - these are the essential conditions for being a people." ${ }^{46}$ This points to the reason why some traditions want to be established on the ground of some heroic or glorious past. It is not always the case, however, that traditions are established with the sole goal to emphasize and support the heroic past. Eric Hobsbawm shows that in fact traditions - similarly to nations - can be invented at the expense of older or even other traditions. ${ }^{47}$ Therefore, Hobsbawm's Invented Traditions are closely related to Benedict Anderson's Imagined Communities since they both support the idea that certain practices can be invented and recognized.

\footnotetext{
${ }^{44}$ Ibid, 55.

${ }^{45}$ Eric Hobsbawm, "Introduction: Inventing Traditions" in Nationalism: Critical Concepts in Political Science, edited by John Hutchinson and Anthony D. Smith, Volume 1 (London, New York: Routledge, 2000), 375.

${ }^{46}$ Ernest Renan, "From "What is a Nation?"' in Collective Memory Reader, edited by Jeffrey Olick, Vered Vinitzky-Seroussi and Daniel Levy (Oxford University Press, 2011), 82.

${ }^{47}$ Hobsbawm, 375.
} 
Sometimes, however, Hobsbawm's arguments do not seem persuasive when he argues about the existence of some genuine traditions where new traditions cannot be substituted or invented. ${ }^{48}$ In this case, the problem lies in the definition of genuine traditions and the understanding of what can make one tradition protected from being re-invented. It seems, however, that overall public and cultural acceptance of a tradition as a repetitive symbolic practice among a society's members can protect it from receding into oblivion or being re-invented in the future. In terms of governmentally mediated representations or practices such as commemorations or national symbols, their public acceptance may be achieved more easily, especially in states with weaker civic consciousness and political culture. Therefore, according to Hobsbawm, "invention" of traditions would occur more frequently when a rapid transformation of society weakens or destroys the social patterns for which "old" traditions had been designed. ${ }^{49}$ In the case of Belarus, such rapid social transformation occurred after the breakup of the Soviet system when new independent symbols of Belarus were produced.

The modernist school of thought appears to be successful in its explanatory power with regard to the particular period of Belarus's post-1991 nation-building process. This school of thought, however, fails to explain the sentiments of the alternative national narrative. Indeed, Belarusian linguistic and cultural identity in the sixteenth century partly developed due to the work of Belarusian humanist Francysk Skaryna (Францыск Скарына) who in 1517 published a translation of the Bible in a Belarusian version of Church Slavonic. ${ }^{50}$ Moreover, with the spread of print-capitalism and the works of Francišak Bahuševič (Франиішак Багушэвіч) in 1891, his literate fellow countrymen were able to recognize that they all were Belarusians and that their land's name was Belarus. ${ }^{51}$ The question, however, is whether the process of spreading of the Belarusian language was successful in promotion of

\footnotetext{
${ }^{48}$ Ibid, 381 .

${ }^{49} \mathrm{Ibid}, 378$.

50 Timothy Snyder, Reconstruction of Nations: Poland, Ukraine, Lithuania, Belarus, 1569-1999 (New Haven: Yale University Press, 2003), 19.

${ }^{51}$ Grigory Ioffe, "Understanding Belarus: Belarusian Identity" Europe-Asia Studies, 55, 8 (December, 2003): 1247.
} 
Belarusian political nationalism among the local peasants who in the sixteenth century neither thought in terms of larger political nations, nor were literate to the extent of being able to imagine their sameness through texts in the Belarusian language.

Therefore, the modernist approach is unable to explain the driving force of the alternative national narrative that is visible in the Belarusian political and public sphere simply because it does not recognize deep historical and ethnic roots of the Belarusian nation. Thus, this study's theoretical discussion of the perennialist and the modernist school of thoughts has outlined their applicability to different expressions of Belarusian national narrative, but both fail to recognize the complexity and controversy of the process in general. Mainly, neither of the approaches are able to explain the ideas behind both the official and the alternative national narratives. Therefore, in search of a theory capable of dealing with both narratives, this research moves to the approach outlined by Anthony Smith who is considered as the principal representative of the ethno-symbolist school of thought.

\section{Ethno-Symbolism and Belarusian National Narratives}

If perennialism focuses on ethnic descent of the nations, and modernism on the imagined and invented construction of the nations, the ethno-symbolic approach tries to see a people's symbolic connections throughout history that would allow them to be called a nation. This approach looks at the cultural features of particular communities in its intentions to see a people's historical interconnections. Therefore, such variables as the role of myths, memories, values, traditions and symbols are the focus of this approach. ${ }^{52}$

\footnotetext{
${ }^{52}$ Smith, Nationalism and Modernism, 190.
} 
In general, this approach tries to see the broader and more complicated picture of the development of nations. It tries to distance itself from the idea that the historical nation-building process has been solely elite-oriented and therefore, stresses the importance of complicated relationships between the elite and lower strata of a social system in which the common people also influence the elite through their cultural traditions, vernacular mobilization etc. ${ }^{53}$ Another important feature of the ethnosymbolic school of thought is that it tries to analyze social and cultural patterns over the longue durée, i.e. over the long period of time, the term used in the Annales school of French historiography. By placing the focus on the broader periodization, the approach tries to see the possible influence of early collective cultural identities on the inception of a particular modern nation.

The form of collective cultural identity within this approach is based on the concept of ethnie (French - ethnic community), which is smaller than the nation and allows several ethnies to coexist and interconnect within a particular territory. In general, ethnie means a unit of population with common ancestry myths and historical memories, elements of shared culture, a link with a historic territory and some measure of solidarity. ${ }^{54}$ The relationship of nations to ethnies, however, is rather complicated and therefore cannot be explained by the simple linear progression of their historical interconnection. ${ }^{55}$ Furthermore, even though the ethno-symbolic approach primarily focuses on cultural features of ethnies such as myths and symbols, it does not fully disregard the ethnic constituency of nations in their historical development.

Anthony Smith argues that ethnicity, like history, is crucial to an adequate understanding of nationalism. ${ }^{56}$ He claims that an ethnic community resembles an extended family that extends over time

\footnotetext{
${ }^{53}$ Smith, Nationalism: Theory, 57.

${ }^{54}$ Smith, Nations and Nationalism, 57.

55 Smith, Nationalism: Theory, 58.

${ }^{56}$ Smith, Nationalism and Modernism, 45.
} 
and space to include many generations and many districts in a specific territory. ${ }^{57}$ Furthermore, ethnic continuity and the ethnic past rediscover certain vital memories, values, symbols and myths, without which nationalism would be powerless. ${ }^{58}$

Smith stresses the importance of ethnic symbols that unite national communities. Therefore, the ethno-symbolic understanding of nation implies that smaller units of population that belong to this nation have some degree of shared past and memory together with a degree of common myths and culture. According to Smith, ethnies have had very deep historical roots even before the rise of nationalism. Therefore, in line with this approach, there is a reason to suggest that the Belarusian nation also has some historical ethnies that existed on its territory during the Grand Duchy of Lithuania.

Even though the ethnic constituent of nations is recognized under this approach, ethnies themselves are constituted not by lines of physical descent, but by the sense of continuity, shared memory and collective destiny, i.e. by lines of cultural affinity embodied in distinctive myths, memories, symbols and values retained by a given unit of population. ${ }^{59}$ Therefore, there has to be an understanding of shared past and culture among the members of a particular community rather than simply a biological and ethnic link. Thus, the ethno-symbolic approach is able to explain the nationbuilding patterns of the official national narrative, which is not focused on lines of physical descent from the people of the Grand Duchy of Lithuania, but rather on their symbolic relation to the modern state of Belarus. Furthermore, the official national narrative stresses the cultural and symbolic importance of the Soviet period and culture in making of the modern Belarusian identity.

Therefore, the official national narrative, by recognizing the influence of the medieval period on the Belarusian lands supports the ethno-symbolist argument that ethnie and the ethnic constituent of a nation does not have to be physically connected to a nation's ancestors. Even though the official

\footnotetext{
${ }^{57}$ Ibid, 46.

${ }^{58}$ Ibid, 45 .

${ }^{59}$ Anthony D. Smith, National Identity (Reno: University of Nevada Press, 1991), 29.
} 
Belarusian narrative does not physically connect itself and the Belarusian nation with the Grand Duchy of Lithuania, it partially recognizes the non-physical influence the period had on Belarus's history and on the modern Belarusian state.

Ethnie is a product of dialogue between social groups and institutions in which each generation has to refashion national institutions in the light of myths, memories and culture of the past. ${ }^{60}$ It means that for the ethno-symbolist school of thinking the idea of a connection with the past is important, however, the nation has to renew and retell the myths in order to maintain itself and national consciousness. It, furthermore, means that the nation is an objective social reality rather than continuously constructed phenomenon, as the modernists perceive it.

Both the official and the alternative national narrative in Belarus center their vision of Belarus on Belarusian history. The main difference, however, is that they focus on different historical periods and values to shape their arguments in regard to the nation-building process of modern Belarus. The abovementioned overview of the ethno-symbolist approach shows that it can be applicable both to the official and the alternative national narrative. The competing national narratives, however, emphasize different sets of symbols that they offer to the modern Belarusian nation. If the official national narrative relies on the myths and symbols of the Soviet period, while at the same time disregarding the pre-Soviet and the pre-Imperial past, the alternative national narrative focuses on historical connection of Belarusian ethnie to the modern Belarusian nation, disregarding the Soviet-era symbols and their influence on modern Belarus. In terms of the ethno-symbolist approach, the official national narrative rejects the ethno-cultural influence of the Belarus's pre-Soviet and pre-Imperial past, but the alternative narrative, on the other hand, tends to recognize its cultural, social and ethnic continuity with the modern Belarusian state.

\footnotetext{
${ }^{60}$ Anthony D. Smith, "From the Ethnic Origins of Nations" in Collective Memory Reader, Ed. by Jeffrey Olick, Vered Vinitzky-Seroussi and Daniel Levy (Oxford University Press, 2011), 235.
} 
For the alternative national narrative, the pre-Soviet and the pre-Imperial symbols such as emblems of the Grand Duchy, reenactment festivals, pre-Soviet architecture and others, serve as powerful reminders of the unique culture and ethnic community that existed on Belarusian lands from the thirteenth century to the late nineteenth century. For the official national narrative, on the other hand, the line of ethnic descent is not as important as the role of the Soviet-era symbols and values such as, stability, conservatism, etc.

Therefore, the ethno-symbolic approach to the study of nationalism is best applicable for the empirical part of my research in which I analyze the representations of the official and the alternative national narrative in Belarus's public sphere. The aforementioned approach is able to explain in more exact terms why various Belarusian national narratives tend to focus on different milestones of Belarusian history. This approach is also selected because the perennialist and the modernist approaches fail to account for the complexity of the Belarusian nation-building process in which Belarusian political and cultural nationalism developed relatively later than in other post-Soviet countries such as the Baltic States. More precisely, the perennialist approach fails to explain why the Belarus's official national narrative does not use the glorious Belarusian past in its nation-building choices and mainly relies on the Soviet-era past of Belarus. The modernist approach, on the other hand, fails to explain why the Belarus's alternative national narrative rejects the Soviet-era past since it is the modern and also glorious past that can be used in the nation-building discourse.

Anthony Smith's approach towards the nations and nationalism seems best suited to explain the complicated relationship between the distinct and historical Belarusian culture, and its use in the Belarusian public sphere for the nation-building process. The nation-building process itself, however, does not simply rely on one or another national narrative, but rather on sets of practices and policies that develop people's sense of community and national values that connect people within a particular 
territory. In this case, states' educational systems have had a significant impact on formulating people's perspective and relationship towards the state and its past. Therefore, it is necessary to overview the specific relationship between public education and its role in the nation-building process.

\section{The Role of Education in Nation-Building Process}

In this section the role of education in the nation-building process is analyzed based on the examples of Andy Green's examination of the relationship between education, globalization and state formation, and Abigail Green's empirical case study in the book Fatherlands: State-Building and Nationhood in Nineteenth-Century Germany. Andy Green and Abigail Green provide different models that demonstrate the role of the state in nation-building via education. Abigail Green's nineteenth-century model emphasizes the nation as a unifying concept but Andy Green's twentieth-century model discusses internationalization of education due to globalization and the close geographical proximity of regional actors. Both models are visible in the Belarusian nation-building process at present.

In the book Education, Globalization and the Nation State Andy Green claimed that in a postnational and globalized world the relationship between education and nation-building has changed since governments can no longer use education to promote social cohesion as they did in the past. ${ }^{61}$ Despite the fact that education systems remain national institutions under national control, Andy Green claims that modern states seek to promote more inclusive forms of national identity that respond to the necessity of multinational states to recognize the effects of coexistence with other regional ethnicities. ${ }^{62}$ These ideas go in line with Anthony Smith's thoughts that there is no one "genuine" version of nationalism, as argued by modernist scholars such as Ernest Gellner. Instead, an education system's

\footnotetext{
${ }^{61}$ Andy Green, Education, Globalization and the Nation State (Palgrave Macmillan, 1997), 3.

${ }^{62}$ Green, Education, 5.
} 
primary goal is not to homogenize the population but to unite it around particular common denominators. $^{63}$ Therefore, the mass education system should recognize the plurality of citizens of a state and to unify the population around certain shared values, myths, memories, etc.

Andy Green introduces the concept of a civic-based rather than ethnic-based nation in which ethnic connections are weaker and less emphasized in comparison to people's civic identity within a particular state. According to Green: "[National education] tried to create the civic identity and national consciousness which would bind each to the state and reconcile each to the other, making actual citizens (...). ${ }^{64}$ Moreover, education as a process of state formation appears to be the primary function of early periods of nation-building, or of periods of political reconstruction after crises. ${ }^{65}$

European powers controlled central or local educational institutions through the allocation of funds, inspecting schools, certification of teachers and other measures. ${ }^{66}$ Furthermore, education also became a feature of social organization that would establish an imagined unity of people through linking the present with a nation's particular past. French sociologist Emile Durkheim thought that education acted as a vehicle of social integration through the transmission of culture. ${ }^{67}$ Moreover, it had to be a unifying, state-promoted culture. In this regard, public education through schools was necessary because previous networks of voluntary schools proved incapable of providing universal education without state assistance. ${ }^{68}$ The basic forms of public systems were first established in 1830 s in the German states, France, Holland and Switzerland. In Belarus, despite the fact that Belarusian schools existed prior to 1991, central, and more importantly - a Belarusian rather than Soviet authority able to exercise nationbuilding policies through education - appeared only following its independence after 1991.

\footnotetext{
${ }^{63}$ Smith, Nationalism and Modernism, 40, 41.

${ }^{64}$ Andy Green, "Education, Globalization and the Role of Comparative Research," London Review of Education, 1, 2 (July 2003): 85 .

${ }^{65}$ Andy Green, Education and State Formation: Europe, East Asia and the USA, $2^{\text {nd }}$ edition (Palgrave Macmillan, 2013$), 4$.

${ }^{66}$ Ibid, 12 .

${ }^{67}$ Ibid, 44.

${ }^{68}$ Ibid, 13.
} 
Abigail Green, in Fatherlands: State-Building and Nationhood in Nineteenth Century Germany, discussed another example of how education could be used in nation-building. The nineteenth century German Mittelstaaten (Hanover, Saxony and Württemberg) serves as an example of the successful use of education in the state and nation-building process. After the revolution of 1848 and, more importantly, after the unification of the German states in 1871, education and school books in Germany were used in order to promote certain national sentiments since the unity of German states had to be imagined due to lack of common national denominators, especially in the regions subordinated to Prussia and Austria, and due to previously existing antagonisms between the states. Green claims that the example of German nation-state formation shows the success of state structures that were able to overcome existing "cultural nation" sentiments of pre-modern societies. ${ }^{69}$ Among the national state structures were the system of education and textbooks in particular. More precisely: “(...) school books usually presented Germany as the primary frame of reference for studying and understanding the particular Fatherland and its past.",70

An understanding of Fatherland in the three states would be promoted through poems included in the school curriculum, through the history of a particular state or by stressing the role of past monarchs in shaping German national developments. ${ }^{71}$ Sometimes textbooks would address similar themes presented by different authors from different states to point out similarities and some common narratives that existed between formerly independent German states. Overall, authors of school textbooks were more interested in interpreting past processes and events from the view of national German affairs in the late nineteenth century. There would also be different narratives in textbooks of different German lands. For example, Württemberg textbooks would emphasize Württemberg's cultural

\footnotetext{
${ }^{69}$ Abigail Green, Fatherlands: State-Building and Nationhood in Nineteenth Century Germany (Cambridge: Cambridge University Press, 2001), 6-7.

${ }^{70}$ Ibid, 269.

${ }^{71}$ Ibid.
} 
and scholarly achievements that bore resemblance with other lands. But Hanoverian schoolbooks would pay little attention to culture and focus on the political history of the state. ${ }^{72}$ Therefore, in broader terms, German mass education promoted German values and symbols on the national level in order to replace the regional sentiments that existed in the German lands before the unification of Germany.

First and foremost, Abigail Green's analysis shows that German nationalism had to be reconfigured after the unification in 1871 based on new national values and symbols by the means of state structures in order to pursue a goal of not only political but also national German consolidation. Green's research shows that nationalism had to be promoted within the state among the people in order to establish loyalty and help them reconfigure their sense of communality.

A crucial significance of history textbooks is located in their ability to present and interpret a distinct and remote past that was previously unknown to the audience. Therefore, besides collective consciousness, collective memory is also facilitated by the system of state education since history textbooks cover periods where personal memory is no longer alive and therefore, people's relation to that past has to be directed and mediated by the system of education. Furthermore, as far as state nationbuilding policies are concerned, a specific type of collective memory might be distinguished - political memory.

\section{Political Memory as a Part of Collective Memory}

Learning on national level is usually conducted through state institutions and services such as the system of mass education. In comparison to individuals, institutions do not possess a memory, they rather "make" it for themselves around such memorial signs such as texts, images, monuments, ceremonies

\footnotetext{
${ }^{72}$ Ibid, 283.
} 
etc. ${ }^{73}$ Such institutional memory appears to be facilitated and constructed by the state institutions, and is based on exclusion, selection and separation of the useful from the not useful, and the relevant from the irrelevant. Moreover, a collective memory, in this respect, is a mediated memory that is backed by material media, symbols and practices, which have to be placed into the hearts and minds of people. ${ }^{74}$

Such a type of institutionally produced collective memory can be called political memory and is produced by the official state institutions in the process of mediating memory by symbols, commemorations, monuments, history textbooks, etc. Therefore, collective memory in this research appears as a larger framework for a discussion of a more local political type of collective memory. Keeping in mind that it is never the past itself but rather the representation of past events that acts within a society, it is highly possible that such representation might be altered with the help of a different interpretation of particular events. Precisely this process is seen when several national narratives are developed to produce a single process like, for example, nation-building.

In her article, "Transformations between History and Memory," Aleida Assmann claims that collective memory is in fact an umbrella term that unites several forms of memory such as family memory, interactive group memory, social, political, national and cultural memory. ${ }^{75}$ For my research on Belarusian official and alternative narratives, as well as on Belarusian history textbooks, the concept of political memory appears to be the most suitable since it looks at the rationale behind the will of state institutions to facilitate a certain type of collective memory for nation-building purposes.

Political memory is based on the long-term carriers of external symbols and representations and thus can be transmitted from one generation to another. Despite the fact that the state cannot influence

\footnotetext{
73 Aleida Assmann, "Transformations between History and Memory" Social Research, 75, 1, Collective Memory and Collective Identity (Spring 2008): 55.

${ }^{74}$ Assmann, "Transformations," 55.

${ }^{75}$ Ibid, 55.
} 
the personal memories of its citizens in a direct way, ${ }^{76}$ indirectly it is able to shape and mediate collective memory in various ways, such as through the emplotment of events in a charged and mobilizing narrative, visual and verbal signs, institutions of learning and mass media, public sites and monuments, and commemorations that would reactivate memory and shape collective participation. ${ }^{77}$ In the process of shaping people's memories, the close alliance between the state and the production of history textbooks is of substantial importance.

The history textbook is a part of the education system that, in turn, is an important factor in the nation-state building process. Aleida Assmann claims that education is an important factor because it is through the learning of history that the heterogeneous members of a population are transformed into a homogenous collective with a collective "autobiography." 78 Thus, history textbooks serve as the vehicles of national memory, which in turn, serves as backbone for the nation-state. Furthermore, history textbooks can promote such national values as tolerance, patriotism, and dignity by constructing distinctive heroic narratives. ${ }^{79}$ It is logical that a nation-state would want to emphasize the heroic and glorious past for nation-building purposes; however, the events that are regarded distinct and heroic are also a matter of interpretation by various narratives.

Aleida Assmann concludes that history textbooks and other representations of national narratives can be analyzed on the principles of selectivity, i.e. what kind of facts and interpretations they include in their body. ${ }^{80}$ Keeping in mind that people's memory constructs and perceptions can be changed, in contrast to the past event which cannot, greater attention should be devoted to both - the nation-state and history textbooks - what is the focus of this research. There is also a question, however, as to what kind

\footnotetext{
${ }^{76}$ Aleida Assmann, "To Remember or to Forget: Which Way Out of a Shared History of Violence?" in Memory and Political Change (Palgrave Macmillan, 2012), 53.

77 Assmann, "Transformations," 55-56.

78 Ibid, 64.

${ }^{79}$ Ibid, 64-65.

${ }^{80}$ Ibid, 70.
} 
of past should be brought up in nation-building discourse. Should it be remote, glorious, recent or less distinct?

Answering the question, nation-states turn to a more remote past to provide evidence of their distinct historical roots when recent history denies their claims to nationhood. Furthermore, the portrayal of this remote past is shaped by the need to highlight a symbolic continuity with the present. ${ }^{81}$ By accepting this link between distinct historical roots and nationhood it is possible to claim that Belarus would have to focus on the period of the Grand Duchy of Lithuania as a distinct and glorious past, that is, when a state that was ruled by Belarusians had a crucial influence in the region. The official national narrative, however, does not stress the importance of the medieval ages. Instead, the official narrative is stressing the importance of the Soviet period in the formation of the Belarusian nation. The alternative national narrative, on the other hand, promoted by the opposition groups, focuses on the medieval ages to emphasize distinct and glorious roots of Belarusian people, thus creating two narratives of Belarusian nationhood.

One of the problems with the Belarusian nation-building process and the period of the Grand Duchy of Lithuania is that the collective subjects, the people who remember, did not exist at the time of the events. In this regard, their constitution as subjects goes hand in hand with the continuous creation of the past if the state refers to the medieval past. ${ }^{82}$ This introduces the contested relationship between the official and alternative national narratives in Belarus since only the official narrative can be constructed and facilitated by the state institutions per se. Thus, it is necessary to analyze both narratives in order to comprehend and distinguish between the two. Since there is only one Belarusian set of events and processes that actually happened, each narrative is silencing some events, while emphasizing, highlighting and interpreting others. By doing so, there is a possibility that both narratives might overlap

\footnotetext{
${ }^{81}$ Zerubavel, 107.

${ }^{82}$ Trouillot, 16.
} 
in their interpretations. This relationship between the official and the alternative narratives and their contents is also overviewed later in this thesis.

Even though the theoretical concept of political memory is not the primary theoretical ground for this research, it was necessary to discuss the concept in order to show the existing relationship between the nation-building process and the application of particular usable pasts to activate certain memories with regard to particular periods of Belarusian history. Therefore, there is an interconnection between the collective memory creation and the nation-building process in which both processes interrelate and interact with one another to achieve certain national goals.

\section{Literature Review}

There is a wide variety of works on nationalism and nation-building in the field, however, there is a lack of studies focused on Belarusian nation-building, especially in regard to other regional nations. It is possible to claim that Nicholas Vakar's book Belarussia: The Making of a Nation that was published in 1956 was the first academic study of Belarusian society and therefore the most cited in existing research on Belarus's history. Together with Jan Zaprudnik's Belarus: at a Crossroads of History, published in 1993, these works were at the center of the greater part of existing academic work on Belarus for several decades.

In 1956, according to Nicholas Vakar, before his own research no comprehensive study of

Belarus existed and, moreover, one hardly could speak of the Belarusians as a distinct society. ${ }^{83}$ The situation has improved after 1956, but in the early 1990s researchers still had failed to produce a clear historiography of Belarusian national development. Starting with the 2000s more research started to

\footnotetext{
${ }^{83}$ Vakar, 17.
} 
appear on Belarusian history, identity and, society. In 2003, however, Timothy Snyder claimed that systematic investigation of the Belarusian national failure in the context of the success of other national movements was unprecedented. ${ }^{84}$ The year 2003 also marked the first attempt to understand Belarusian post-Soviet nation-building process by Grigory Ioffe in terms of various narrated models of nationalism. In 2007 Ioffe claimed that Belarus remained one of the least-studied European states to emerge from the breakup of the Soviet Union and therefore little was known about Belarus besides the undemocratic practices of its president, Alyaksandr Lukashenka. ${ }^{85}$ Nevertheless, starting with the early $2000 \mathrm{~s}$ increasing numbers of researchers began working on Belarus in terms of conceptualizing its national development after the breakup of the Soviet Union.

Among such scholars Natalia Leshchenko, Natalia Mamul, Grigory Ioffe, Nelly Bekus and Yuliya Chernyavskaya must be mentioned. They defined various approaches to the study of Belarusian national development such as pro-European, Nativist, pro-Moscow/Russian, pro-Soviet, Creole and others. Furthermore, such scholars as Nelly Bekus and later Renee Buhra distinguished between the official model of Belarusian national development and the alternative model. In this regard, a case study by Tatiana Kasperski about the Chernobyl nuclear accident provides a good example of how these models interpret a particular event from the Belarusian past. ${ }^{86}$

In terms of more comprehensive analyses of Belarus's national development and national discourse, several books might be selected: Belarus - a Perpetual Borderland (2009) by Andrew Savchenko, Struggle Over Identity (2010) by Nelly Bekus and Belarus: the Last Dictatorship in Europe (2011) by Andrew Wilson. These books are extensively used in this research and provide a good analysis of Belarus's domestic nation-building politics. The latest work on Belarusian identity, however,

\footnotetext{
${ }^{84}$ Snyder, 9.

${ }^{85}$ Ioffe, Culture Wars, 348.

${ }^{86}$ Tatiana Kasperski, "The Chernobyl Nuclear Accident and Identity Strategies in Belarus" in History, Memory and Politics in Central and Eastern Europe: Memory Games, edited by Georges Mink and Laure Neumayer (New York: Palgrave Macmillan, 2013).
} 
is that of by Francois Zdanowicz, whose dissertation Myths of Nationhood and Support for State Sovereignty in Belarus was defended in 2013. It is a comprehensive analysis of Belarusian national development narratives.

It should be concluded that there is a lack of existing research on Belarusian history textbooks, especially in terms of focused narrative analysis of a particular nation's representation. Tatyana Ostrovskaya so far had conducted the most comprehensive research in 2010 when she analyzed Belarusian history textbooks published from 1993 until 2009. Her research, however, leaves room for additional research on Belarusian history textbooks because it was confined to an analysis of narrative rather than an examination of other nations' representation. Therefore, this particular research contributes to the existing knowledge on the Belarusian post-Soviet nation-building process, as well as presents one of the first academic analyses of the representation of Lithuania in Belarusian history textbooks published in 2009 and 2010.

\section{The Research Methodology}

While some scholars might underestimate the relevance of studying history textbooks and neglect such a study's ability to produce consistently germane conclusions, for historians, according to John Inssitt, “(...) the process of unpacking various elements reflected and expressed in textbooks is richly

revealing. ${ }^{87}$ It is especially revealing to study the narrative of history textbooks in terms of the role of education in the nation-building process, as well as construction of knowledge and manipulative ability of state power and ideology.

\footnotetext{
${ }^{87}$ John Inssitt, "Reflections on the study of textbooks" History of Education, Vol. 33, No. 6 (November, 2004): 685.
} 
Representations of the Belarusian national narrative and the representation of Lithuania in Belarusian history textbooks are the focus of this research. Therefore, the research methodology lies in the interpretive approach to analysis of narrative constructed by the textbooks and its intent. ${ }^{88}$ This approach to textbook analysis is concerned with the content rather than procedure through which the content had been acquired. Recognizing the complex relationship between the nation-building process and education, this research also incorporates selective analysis of political speeches and statements around the Belarusian nation-building process made by the President Lukashenka together with the present-day expressions of Belarusian nationalism in various forms. Analysis of political speeches in this research is used to portray the certain relationship between the events "on the ground" and the political statements made by President Lukashenka himself. Lukashenka's speeches, therefore, are mainly used to justify certain conclusions made by the author, or to signalize the beginning of particular processes initiated, or marked by the President. Textbook analysis, however, is the central part of this research.

The method of narrative analysis employed by this study can be closely related to the qualitative method of research where narratives are analyzed by themes and categories ${ }^{89}$ Overall, narrative research uses literary devices and allows multiple interpretations by multiple readers. Therefore, the task of narrative inquiry is not to describe a phenomenon as it is but to re-describe the events or phenomena by offering various interpretations to the reader. ${ }^{90}$ Furthermore, interpretation of not only the texts is valuable but also looking at visual representations of narratives might support or refute certain assumptions. Visual illustrations are especially capable of emphasizing the narrative of another nation's

\footnotetext{
${ }^{88}$ Frederick Erickson, "Qualitative Methods in Research on Teaching” Handbook of Research on Teaching, edited by Merlin Wittrock (New York: MacMillan, 1986), 120.

${ }^{89}$ Cathy Coulter and Mary Lee Smith, "The Construction Zone: Literary Elements in Narrative Research" Educational Researcher 38, 8 (2009): 577.

${ }^{90}$ Cathy Coulter and Mary Lee Smith, 578.
} 
representation in Belarusian history textbooks. In this work, textbook narratives are interpreted with regard to various expressions of national narrative in the Belarusian public space.

Interpretivist narrative researchers conduct their analysis by reading the body of evidence as a whole and then generating assertions. Each assertion is later affirmed or discarded and for each surviving assertion a vignette is constructed that demonstrates the truth of the assertion in narrative form. Thereafter, an assertion is framed in interpretive commentary with relevant data. ${ }^{91}$ In terms of this research, the assertions from Belarus's official national narrative in history textbooks were framed within the context of Belarusian nation-building process and the binary opposition between the official and the alternative national narratives.

For this study, four history textbooks published in 2009 and 2010 were analyzed from Belarus's schools with Russian as the language of instruction. The choice of textbooks was made on the basis of existing research conducted by Tatyana Ostrovskaya. This existing research helped to define textbooks from which grades should be used to cover the necessary periodization. In terms of periodization, this research mainly focuses on the period of the Grand Duchy of Lithuania in Belarus's history textbooks, which covered the time from the mid-thirteenth century until 1795 when it was partitioned and became the part of the Russian Empire. In addition, Ostrovskaya concluded that the textbooks from 2009 and 2010 represented the post-2002 national narrative in its content, which I will explain later in this research. All four textbooks were closely read by the author with regard to particular chapters about Belarus's medieval past and the history of the Grand Duchy of Lithuania in particular.

The text and the interpretation of the textbooks' content are central to my methodology; however, the maps used in the textbooks were also evaluated. Therefore, historical narratives of the textbooks were interpreted with regard to the representation of Belarus's national narrative in general and the representation of Lithuania and the Lithuanians in particular. It was very important to understand

\footnotetext{
${ }^{91}$ Coulter and Smith, 587.
} 
the general attitude of the textbooks' narratives towards the research objects; thus, particular attention was devoted to particular words and visual representations that were used in the textbooks to describe the role of the Belarusians and of the Lithuanians in relation to the Grand Duchy of Lithuania. After understanding the general trends and narrative patterns, this author has retold the narrative story, with particular interpretation of the narrative in terms of its belonging to the official or the alternative national narrative of Belarus's history. In terms of the representation of the Lithuanians, the author constructed a particular narrative using the information provided in the textbooks in order to conclude how the Lithuanians themselves and their role was portrayed in regard to the creation and maintenance of the Grand Duchy of Lithuania.

It is believed that such a research method is able to answer the research question, satisfy the research aim, and to evaluate the hypotheses. Responding to concerns expressed by some of the Lithuanian historians, this research tries to answer the question whether the Belarus's history textbooks are "rewriting" the Lithuanian past. Initially, however, the research has a broader aim and tries to understand the Belarus's nation-building process in general. The process of conducting the research revealed the complexity of the Belarus's nation-building case in which several periods of national development can be pointed out since 1991. Furthermore, because of its relative underdevelopment, the present condition of Belarus's nationalism is quite different from the experience of other regional actors, thus making the research even more fascinating. Therefore, the author also asks broader questions in regard to Belarus's domestic nation-building process and its relationship to Belarus's foreign policy choices since 1991.

Based on preliminary research and several existing assumptions, two hypotheses were formulated. First: the Belarusian national narrative in history textbooks does not challenge the Lithuanian national narrative, but seeks to highlight and empower the "Belarusianness" of their shared 
past for the nation-building purposes. Second: the more the official Belarusian narrative tries to establish a Belarusian national idea, the more it resembles the alternative narrative of Belarusian opposition. It is believed that the research and the empirical case study, supplemented by the methodology and the theoretical framework, are able to evaluate the hypotheses, answer the research question and achieve the aim of the research.

It is believed that the methodology and the theoretical framework are able to illuminate and explain the empirical part of the thesis in particular. As outlined earlier in this chapter, the explanatory power of the ethno-symbolist approach to nationalism studies is able to understand the present condition of Belarus's nation-building process. Moreover, the ethno-symbolist approach is able to explain why the official and the alternative narratives, which exist in Belarus's public sphere focus on different historical periods, values and myths in their work to achieve rather similar goals - to unite the Belarusian nation. In comparison, the perennialist and the modernist approaches to nationalism studies fail to explain the logic behind both narratives even though they may explain some of the narratives separately.

It is also believed that the interpretive methodology is suitable for the analysis of history textbooks because it is the text and the meaning of the textbooks' narrative that is in the focus of the study. Therefore, by interpreting the narrative using the existing knowledge on Belarus's nationalism it is possible to evaluate whether the textbooks' narrative supports the official national narrative and whether it contains certain sentiments towards the alternative national narrative. Regarding the representation of Lithuanians in Belarus's history textbooks, there is a certain narrative which can be uncovered differently by different scholars. Therefore, the interpretive method is suitable for the intentions of my particular research to try to evaluate the narrative in terms of the Belarus's complicated nation-building process. Thus, it seems that the methodology is successful in helping to conduct the empirical part of my research. 
Qualitative methods may be more successful with regard to understanding the way information is presented; however, it is hard to make generalizations from such qualitative textbook analyses. ${ }^{92}$ Therefore, this narrative research is unable to provide a general framework for analysis of Belarusian history textbooks with regard to various expressions of Belarusian national narrative. The stronger side of the method, however, is that the knowledge is constructed through transactions among academic research, participants, evidence and the social context of the phenomena. ${ }^{93}$ Thus, the Belarusian national narrative has to be treated as a complex phenomenon that is produced by the multifaceted process of interaction between various actors.

School curriculum, furthermore, is the knowledge system of a society incorporating its values and its dominant ideology. ${ }^{94}$ Therefore, conducting interpretive narrative research allows one to see the interaction between the dominant ideology in the official discourse and the public sphere, i.e. how are the dominant ideas reflected in the school curriculum and vice versa. In order to broaden the possible application of history textbooks research, it is supplemented with the analysis of the official documents of the Republic of Belarus that cover the study of the subject "World History. History of Belarus." This is done in order to analyze whether the official documents resemble the ideals and values of the official national narrative that is facilitated by the government itself. This research, however, also looks at media and public campaigns/initiatives that might emphasize different ideas from the state-promoted official national narrative. In this regard, different expressions of Belarusian nationalism are interpreted to see the possible meaning of such public expressions with regard to the predefined criteria of the official and the alternative national narratives.

\footnotetext{
92 Jason Nicholis, "Methods in School Textbook Research" International Journal of Historical Learning, Teaching and Research 3, 2 (2003a): 13.

${ }^{93}$ Coulter and Smith, 588.

94 Keith Crawford, "The Role and Purpose of Textbooks" International Journal of Historical Learning, Teaching and Research 3, 2 (2003a): 7.
} 


\section{CHAPTER TWO: UNDERSTANDING BELARUSIAN NATIONALISM}

By recognizing the complexity and diversity of Belarusian nation-building, this research, on the empirical level, also challenges the view that Belarus is a "denationalized" space that failed to produce a consolidated nation after the dissolution of the Soviet Union. Contrary to the assumption that a Belarusian nation "failed" to form, this chapter tends to recognize and understand the ongoing process of Belarusian nation-building, starting in the thirteenth century.

The first chapter outlined different perceptions of nationalism as understood by primordialist and modernist/constructivist scholars. It was agreed that some of the approaches tend to offer better explanation of nationalism according to different configurations in particular case studies. Trying to understand Belarusian nationalism, Alexander Pershai questioned the existing nationalism paradigms in their application to the expressions of Belarusian nationalism in particular. By doing so, he used a conceptual relationship of major/minor suggested by Gilles Deleuze and Felix Guattari. ${ }^{95}$ Pershai questions existing paradigms of nationalism studies which tend to distinguish between clichés of "developed," "underdeveloped" and "developing" nations. According to existing paradigms, the Belarusian nation is still in the process of development and, moreover, is considered to resemble an example of the "delayed" nationalism. According to major/minor relationship, however, Pershai claims that Belarusians emerged as a nation a long time ago, but due to the political, historical, economic and regional peculiarities it developed into an "unconventional," minor form of nationalism. ${ }^{96}$ In this regard, the author concludes, that it is valuable to question the essence of modern nationalism discourse and

\footnotetext{
95 Alexander Pershai, "Minor Nation: The Alternative Modes of Belarusian Nationalism" East European Politics and Societies 24, 3 (Summer 2010): 389. Major/Minor relationship is distinguished between the two kinds of languages, i.e. "high" and "low." This relationship is not precisely a matter of domination but rather a matter of assigning one language (major) an imperialist power over minor languages. Furthermore, major/minor relationship exists only in relation to one another where the major language also invests in making another language a minor.

${ }^{96}$ Ibid, 393.
} 
change the existing paradigms of evaluating nations according to criteria that are not universal and no longer reflect the state of modern nations.

Pershai's critique of modern scholarship is also applicable to Benedict Anderson's understanding of nations because it is based on the rejection of totalities such as a sole focus on language. Moreover, Pershai claims: “(...) the rejection of totalities is the key for understanding the alternative modes of nationalism in Belarus. ${ }^{.97}$ It is a valuable critique of not only modern paradigms of nationalism but also of the alternative narrative of Belarusian nationalism since it tends to rely on the existing framework of Western nationalism studies such as those discussed in the theoretical framework for this dissertation.

It is useful to question the explanatory power of nationalism studies with regard to particular empirical cases. Alexander Pershai's research introduces a complicated example of Belarusian national consciousness that has been shaped by various actors within and outside the Belarusian state. More precisely, the debate on Belarusian nationalism has been shaped by Western and Belarusian scholars whose research is rarely connected and, furthermore, aimed at different audiences. ${ }^{98}$ Thus, it is necessary to incorporate a broader possible debate on the question of Belarusian nationalism and its development through time and space. This discussion starts with the time when Belarus acquired its independence in 1991.

\section{Belarusian Identity Politics 1991-2002}

The political nationalism of modern Belarus was born in 1988 when a mass grave of thousands of bodies was found in Kurapaty, on the outskirts of Minsk. ${ }^{99}$ Public reaction resulted in the creation of Belarusian Popular Front (BPF) that was established in October of the same year and was led by Zianon Pazniak

\footnotetext{
${ }^{97}$ Ibid, 394.

${ }^{98}$ Ibid, 382.

${ }^{99}$ Savchenko, 150.
} 
(Зянон Пазняк). ${ }^{100}$ After the proclamation of Belarusian independence, the BPF became the leading organization in formulating a Belarusian political agenda and nation-building policies. The BPF's national narrative can be called pro-Western, pro-European and Nativist since it focused on the preSoviet Belarusian past, identifying Belarusian history primarily with Europe and the period of the Grand Duchy of Lithuania. The national policies of the BPF and post-Soviet Belarus resembled the classical identity-creating steps of countries recently liberated from imperial domination. ${ }^{101}$ The nation-building policies in post-Soviet Belarus, however, were affected by the strong dependency of the new Belarusian economy on the Russian Federation together with the strong presence of the Russian military forces and strategic bases on the territory of independent Belarus.

In this regard, the BPF's nation-building task in the newly established state was rather obscured by the country's strong economic and military dependency on Russia. In 1992, 10 percent of Belarus was under the jurisdiction of "military structures" primarily used by Russia. Furthermore, there were even strong concerns whether Belarus would be able to develop a "national army" since its army did not really reflect the ethnic makeup of the republic's population and was controlled mainly by the proRussian oriented command. ${ }^{102}$ In 1992, the Belarusian Prime Minister from the BPF Vyacheslav Kebich (Вячаслаў Кебіч) said: "If we are a nation, we should have our own national relics. With the poor national arsenal we have received in all spheres of our spiritual life, we can hardly convince our contemporaries and descendants that we have a history of our own." ${ }^{, 103}$ It signified that Belarus had to transform its post-Soviet state in order to develop an independent national narrative that would allow for an emphasis on Belarus's distinct historical past.

\footnotetext{
${ }^{100}$ Ioffe, Culture Wars, 355.

${ }^{101}$ Natalia Leshchenko, "A fine instrument: two nation-building strategies in post-Soviet Belarus" Nations and Nationalism 10, 3 (2004): 334.

${ }^{102}$ Jan Zaprudnik, "Development of Belarusian National Identity and Its Influence on Belarus's Foreign Policy Orientation" in National Identity and Ethnicity in Russia and the New States of Eurasia, ed. Roman Szporluk (New York: M.E. Sharpe, 1994): 136.

103 Astrid Sahm, "Political Culture and National Symbols: Their Impact on the Belarusian National-Building Process" Nationalities Papers 27, 4 (1999): 652.
} 
One of important steps in a state's nation-building process is the country's capacity independent economic development. Other post-Soviet countries such as the Baltic States had already completed the privatization process of small enterprises by 1994 and had initiated free market economic reforms. In Belarus, however, this process was much slower. Moreover, it seems that the BPF failed to successfully privatize large and small enterprises that would allow the country to continue its neoliberal reforms. Even though Belarus intentionally was moving towards a market economy in 1990s, the process had been relatively slow and later even reversed by the Lukashenka administration in 1994 when the administration decided to preserve the economic structure of Belarus as close to its original Soviet shape as possible. $^{104}$

The BPF's nation-building policies, for their part, failed to produce a strong appeal for a Belarusian distinct past and due to ethnocentrism it could not incorporate large numbers of nonBelarusian peoples who did not speak Belarusian. The BPF was too nationalistic in its vision and wanted to make Belarus more "Belarusian" in terms of Belarusian language and distinct Belarusian symbols. The BPF considered the Grand Duchy of Lithuania a Belarusian state and claimed that the Soviet period was a tragic mistake. ${ }^{105}$ The BPF failed to recognize still existing sentiments towards the Soviet Union and dismissed the Soviet period that constituted an important part of people's lives. Collective memory of the Soviet period in 1990s was still living and too strong to be dismantled by the political nationalism of the BPF. The primary success of the BPF, however, was in its promotion of visual manifestations of a new, post-Soviet Belarusian identity.

In 1991 the Supreme Soviet adopted the white-red-white flag and the coat of arms, called Pahonia, as new national symbols of the independent Republic, thus directly linking post-Soviet Belarus with the political entity of the Grand Duchy of Lithuania since Pahonia was also a symbol of the Grand

\footnotetext{
${ }^{104}$ Savchenko, 163.

${ }^{105}$ Leshchenko, 337.
} 
Duchy. Nowadays, these symbols are associated with the Belarusian political opposition, as well as with the alternative expressions of the Belarusian nationalism. Even though the BPF stood for the fair representation of Belarusian history, many scholars claim that its political failure was due to its definition of the nation and expressions of nationalism that were not applicable to the demographic and linguistic composition of the post-Soviet state. ${ }^{106}$ Even though there were around 80 percent of Belarusians in the state in the 1990s, only around 40 percent would claim Belarusian as the language they spoke at home. ${ }^{107}$ The BPF, however, built its nation-building campaign by emphasizing the use of Belarusian language in everyday life that did not coincide with the rather pro-Russian sentiments of the post-Soviet society. In other words, the BPF got the idea of Belarusian nationalism wrong, but the new President Alyaksandr Lukashenka got it right.

The period from 1991 until the election of Alyaksandr Lukashenka in 1994 was characterized by the development of what is today known as the alternative national narrative. The introduction of the "new past" in the early 1990s started with the draft of the new Belarusian constitution that spoke for a “(...) centuries-old development of Belarusian statehood" that was "reflected in the Statutes of the Grand Duchy of Lithuania, the Constituent Charters of the Belarusian Democratic Republic, and the Constitutions of the Belarusian Soviet Socialist Republic." 108 Thus, the early independent republic mainly focused on the pre-Soviet and pre-Imperial Belarusian identity that had been developing in various forms since the thirteenth century. Already at the beginning of the 1990s, however, the BPF was not the only entity to represent an alternative version of Belarusian nationalism in Belarusian public sphere. More ephemeral satellite groups like "Talaka" or "Martyrolah Belarusi" developed in Belarus

\footnotetext{
${ }^{106}$ See, for example Natalia Leshchenko, "A fine instrument: two nation-building strategies in post-Soviet Belarus" Nations and Nationalism 10 (3), (2004): 337. Astrid Sahm, "Political Culture and National Symbols: Their Impact on the Belarusian National-Building Process" Nationalities Papers 27, 4 (1999): 652. Andrew Wilson, Belarus: the Last Dictatorship in Europe (New Haven, London: Yale University Press, 2011), 258. Andrew Savchenko, Belarus - A Perpetual Borderland (Leiden, Boston: Brill, 2009), 173.

107 Нина Мечковская, «Почему в постсоветской Беларуси всё меньше говорят на белорусском языке?» Неприкосновенный Запас № 6, 80 (2011).

${ }^{108}$ Jan Zaprudnik, Development of Belarusian National Identity, 132.
} 
that expressed certain narratives, which were different from the Soviet interpretation of Belarusian nationalism, however, were less political in comparison to that of the BPF. ${ }^{109}$

Alternative expressions of Belarusian nationalism do not exist as a single concept like the official national narrative. ${ }^{110}$ Even though the 1991-1994 narrative was considered official at that time, presently, the same narrative refers to the alternative vision of Belarusian national development since the groups that supported it in the 1990s are now in opposition to the present Belarusian government. In this regard, the alternative national narrative is seen as an aggregate of various narratives that do not correspond to the official narrative promoted and maintained by the Belarusian government. Thus, in comparison to the official narrative, which can be summarized by looking at official representations, discourse and state systems such as education, the alternative narrative appears in a form of public discourse that takes place in public media, Internet, public space, academia, as well as various nongovernmental and oppositional bodies.

Therefore, the alternative national narrative can be defined as a set of ideas about Belarusian national development and present nation-building policies that contradict the official national narrative in terms of what is considered to better characterize the modern Belarusian nation. For example, the official narrative considers the day when Minsk was liberated from the German forces during the Second World War to be more important for modern Belarusian history rather than the day when Belarus proclaimed its independence in 1991. Moreover, the official narrative tends to distance Belarusian history from the Grand Duchy of Lithuania claiming that it does not fully reflect modern Belarus's values. The alternative narrative, on the other hand, sees modern Belarus as a political entity that developed from the Grand Duchy of Lithuania. The alternative narrative also claims that Belarusian language developed from the "Rusky" language of the Grand Duchy of Lithuania, but the apogee of

\footnotetext{
${ }^{109}$ Savchenko, 156.

${ }^{110}$ Nelly Bekus, "European Belarus versus State Ideology: Construction of the Nation in the Belarusian Political Discourses" Polish Sociological Review, 163 (2008): 197.
} 
political development took place in 1918 when Belarusian People's Republic was proclaimed. ${ }^{111}$ Thus, the alternative narrative rejects the Soviet past in its intentions to define independent Belarusian nation on the basis of the pre-Soviet past.

During the process of nation-building in early 1990s in educational and cultural institutions, the Belarusian language was steadily replacing Russian and the majority of society gradually accepted such changes. ${ }^{12}$ Furthermore, the language policy and visible ethnocentrism became the most evident signs of change from the Soviet period; it was planned that by 1999 all Belarusian universities would switch to Belarusian as the main language of instruction. It was a hard task, however, because the Belarusian people did not really speak the Belarusian language on the same level as Russian; moreover, they had a stronger identification with the Soviet Union than with the new republic. ${ }^{113}$ Identification with panRussian identity and fears of a stronger Belarusian nationalism resulted in the victory of the populist candidate Alyaksandr Lukashenka who after 1994 consolidated his power and engaged in the construction of a rather eclectic form of Belarusian identity. More precisely, Lukashenka offered stability and security together with a good "golden past" that was closer to the still existing Soviet mentality of the Belarusian people, unlike the pre-Soviet past offered by the BPF. ${ }^{114}$

The overall task of the BPF in early 1990s was quite complicated since it wanted to foster a Belarusian historical past connected to the West, but the country's economic dependency together with its military dependency on Russia kept Belarus tightly connected to a Russian and Eastern orientation rather than a Western one. Together with shortsighted ethnocentric national policy and lack of a strong presidential candidate, the BPF was unable to succeed in the first Belarusian presidential elections of

\footnotetext{
${ }^{111}$ Ioffe, Understanding Belarus, 1255.

112 Eugeniusz Mironowicz and Jerzyna Slomczynska, "The Attitudes of Belarusians and Poles towards the Independence of Their Countries" International Journal of Sociology, 31, 4, Belarus: Between the East and the West (II) (Winter 2001/2002): 87.

${ }^{113}$ Wilson, 141.

${ }^{114}$ Leshchenko, 340.
} 
1994. Soon after the elections, Lukashenka started reintroducing the pro-Soviet version of Belarusian nationhood that was mainly connected with the Belarusian SSR, the indigenization policies of the Soviet Union, as well as the Second World War, as the unifying elements of the nation. In 1995 Lukashenka started a campaign against independent historians and withdrew post-1991 history textbooks from Belarusian schools, reintroducing the Soviet edition of textbooks. ${ }^{115}$ The Soviet textbooks, therefore, stressed Belarusian joint historical development with Russians in a common state together with the emphasis of Belarusian national glory during the Second World War. ${ }^{116}$

In a symbolic way, the Soviet-era history textbooks reintroduced the notion of a Belarusian nation being developed mainly with the help of the Soviet Union in 1920s, which had been part of the collective memory before 1991. Moreover, the political memory about the Soviet past started to be promoted by the government itself via the centralized system of mass education. The Soviet-era textbooks once again stressed Belarusian joint historical development with Russia in a common state together with the emphasis of Belarusian national glory during the Second World War. ${ }^{117}$ With the reintroduction of the Soviet-era textbooks a reactionary turn took place without any real intention to consolidate a national idea that would stress merits of the independent Belarusian state. ${ }^{118}$ The Belarusian researcher Tatyana Ostrovskaya concluded in her research that the post-1995 period was characterized by intentions to fight the Belarusian nation-building project that had been formed during the 1991-1994 period. In the Soviet-era history textbooks Belarusians were characterized as Slavs, West-Russians and Russians. Thus, it is possible to conclude that Lukashenka's first nation-building policies were rather reactionary and focused on elimination of ideas that Belarus was an independent and different country from Russia. One important aspect of this period is that the government's

\footnotetext{
115 The Human Rights Watch www.hrw.org "Reviving Soviet History" in Republic of Belarus: Violations of Academic Freedom 11, 7 (D) (July 1999), available: http://www.hrw.org/reports/1999/belarus/Belrus99-05.htm

${ }^{116}$ Wilson, 172.

${ }^{117}$ Ibid.

118 Островская, 6.
} 
facilitated political memory tended to develop the idea that Belarusians had been called Russians throughout Belarus's history.

1995 should be considered the year when the state began to promote a political memory that did not want to recognize Belarus's pre-Soviet past. It is also the year, however, when the official national narrative of the Lukashenka's regime started to develop. The official narrative is defined as a set of ideas about Belarusian national development and present nation-building policies that are characterized by the Russophile and pro-Soviet orientation that stems from the Orthodox cultural tradition where Russian is seen as the prime cultural donor playing a pivotal role in shaping Belarus' statehood. ${ }^{119}$ The post-1995 narrative is characterized by the acceptance of the Soviet heritage and Belarusian present as the preservation of all the best from the Soviet life. Such values as stability and security dominated over claims to individuality. Furthermore, the pro-Russian narrative saw Russia as the main strategic partner for the economic and political development of Belarus. ${ }^{120}$ Furthermore, Russophile historiography saw Belarusian identity tied to Russian and eastern Slavic territories of Kievan Rus' while ignoring repressions of the Belarusian identity during the nineteenth century and the Soviet period in general. ${ }^{121}$

The Soviet period within the framework of the official narrative is seen as a time when Belarusian identity was recognized politically and linguistically, especially in 1920s when the Belarus Soviet Socialist Republic was established. The Soviet territory of Belarus in 1920s, under the policy of indigenization (korenizatsiya), was able to develop certain national consciousness and representation within the USSR. At some point, even the attempt to recreate the medieval Grand Duchy of Lithuania was taken under the name "Lit-Bel." ${ }^{, 22}$ Even though the "Lit-Bel" project gradually vanished, Moscow

\footnotetext{
${ }^{119}$ Ioffe, Understanding Belarus, 1267.

120 Yaroslav Shimov, "Belorussia: Vostochnoevropeiskii paradoks" Neprikosnovennyi zapas 3 (2006),http://magazines.russ.ru/nz/2006/47/sh11.html

${ }^{121}$ Taras Kuzio, "History, Memory and National Building in the Post-Soviet Colonial Space" Nationalities Papers 30, 2 (2002): 255.

${ }^{122}$ Wilson, 98.
} 
supported Belarusian culture in various ways: schools with Belarusian language of instruction were opened, a republican Academy of Science was established together with the Belarusian State University, Institute of Belarusian Culture, State Library etc. ${ }^{123}$ Such Belarusian poets as Yanka Kupala (Янка Купала) and Yakub Kolas (Якуб Колас) promoted Belarusian national-consciousness in culture. In 1920 Yanka Kupala wrote a play Tuteysha (The Locals) where he created a cultural term of Belarusian local individualism mentioned earlier - mутэйшасиь. ${ }^{124}$ Yakub Kolas also promoted the vital characteristic of Belarusian mentality - local consciousness. These poets are largely recognized by the Lukashenka regime and their presence is maintained in Belarusian collective memory through the public space, for example, one of the main squares in Minsk is named after Yakub Kolas and one of the parks near the Presidential palace is called after Yanka Kupala.

Lukashenka's first years in office also marked a symbolical change from the 1991-1994 narrative. Less than a year after the elections of May 14, 1995 a referendum was held in which voters were asked if they wanted to give the same status to the Russian language as to Belarusian, to replace the Belarusian flag and coat of arms with new symbols derived from Soviet period, and whether people supported Lukashenka's economic policy towards greater integration with Russia. ${ }^{125}$ Another, nonbinding question was asked if people agreed to amend the 1994 Constitution and allow the President to dissolve the Supreme Soviet in case of necessity. In public voting, the Belarusian people supported all four questions and thus expressed their dissatisfaction with the policy of previous government led by the BPF. The fourth question, however, had the most far-reaching consequences for the political changes in Belarus in the upcoming years.

The new state symbols were directly taken from the Belarus's Soviet past. In 1953 the Belarus Soviet Socialist Republic had adopted a new flag with Belarusian ornaments on the left side, hammer

\footnotetext{
${ }^{123}$ Snyder, 65.

${ }_{124}^{12}$ Юлия Чернявская, Белорусы: от "тутэйшых" к нации (Минск: ФУАинформ, 2010), 33.

${ }^{125}$ Savchenko, 183.
} 
and sickle in the left corner, green stripe on the bottom and the main body in red. The referendum of 1995 re-invented the Soviet-style flag by changing the structure of the ornament and removing the obvious symbols of the Soviet Union - the hammer and sickle. The 1991-1995 symbols were now presented as an artificial invention of the Belarusian Central Council in 1943-1944, thus breaking the historical connection with the Grand Duchy of Lithuania. ${ }^{126}$ After the referendum, the new state symbols had to be introduced to people's daily lives. Thus, the display of the new flag and coat of arms became compulsory for state institutions; the Pahonia emblem itself was taken off Belarusian passports in December 1996. Furthermore, Belarusian Independence Day was transferred from July 27, when the sovereignty from the Soviet Union was declared, to July 3, when Minsk was liberated from Nazi occupation during the Second World War. ${ }^{127}$ It was a symbolic break with the national narrative introduced by the BPF in early 1990s. Lukashenka's domestic policies, however, had even greater implications for Belarusian political representation in the region and bilateral relations with Russia.

In a second referendum of November 24, 1996 the Belarusian people supported an increase in the president's powers together with the pro-Russian direction of Belarus's national development. Voters allowed the President to appoint local administrators, thus establishing a presidential vertical structure of power. ${ }^{128}$ The referendum also expressed symbolic agreement with Lukashenka's proRussian policies. Domestic discourse about the close historical association of Belarus and Russia allowed Belarus to request greater political integration with Russia. First, Belarus and Russia signed a Treaty of Friendship and Cooperation in February 1995 which allowed the Russian military to continue using military facilities on Belarusian soil. Later, a Customs Union was signed allowing Belarusian manufacturers to reestablish the Soviet-era supply chain that strongly relied on Russian goods. On April 2, 1996, a treaty on the formation of a commonwealth between Belarus and Russia was signed, creating

\footnotetext{
${ }^{126}$ Wilson, 172.

${ }^{127}$ Leshchenko, 338.

${ }^{128}$ Savchenko, 187.
} 
several supra-national institutions like the Supreme Council, the Executive Committee, and the Parliamentary Assembly. The apogee, however, was achieved on December 8, 1999 when the Treaty on the Creation of the Union State of Russia and Belarus was signed, proposing a greater integration of the two states in political, economic, military, monetary and judicial terms. ${ }^{129}$

Thus, reconsideration of the Belarusian national narrative supported the direct policy of political and economic integration with the Russian Federation. It is hard to claim what would have happened if Boris Yeltsin had remained President of Russia. His successor Vladimir Putin, however, did not share the same vision of bilateral integration on equal terms. More precisely, in summer 2002, Vladimir Putin claimed that the only possible way of integration of the two states was Belarus's incorporation into the Russian Federation. ${ }^{130}$ Obviously, it was not an acceptable way for Belarus to claim its identity within a union with Russia and maintain regional representation.

Even though Lukashenka exercised pro-Russian nation-building politics, he still remained proBelarusian in his own way. In terms of the post-2002 nation-building politics, Lukashenka can be understood as "the main anti-Belarusian nationalist of Belarus." "131 After 2002, some researchers claim that Lukashenka started to exercise the Creole way of nation-building by recognizing both the proRussian narrative and the Soviet influence together with the distinct pre-Soviet historical past of Belarus. ${ }^{132}$ Thus, Lukashenka started shifting towards an understanding that Belarusian identity was essentially different from its Soviet and Russian counterparts even though it was largely produced under their influence.

It is reasonable to suggest that both aforementioned narratives have been contributing to Belarusian identity; however, they primarily focused on different historical periods, as well as different

\footnotetext{
${ }^{129}$ Ibid, 209.

${ }^{130}$ Leshchenko, 341.

${ }^{131}$ Ioffe, Culture Wars, 367.

${ }^{132}$ The concept of Creole is defined on the basis of Benedict Anderson's definition of Creole states as communities who shared a common language and common descent with those against whom they rebelled; Anderson, 47.
} 
values that the Belarusian people possessed. If the Nativist narrative stressed Belarusian individuality together with its distinct historical past, then the pro-Soviet narrative emphasized Belarusian collectivity and the historical connection with Russia within the Soviet Union. The situation, however, changed after 2002 when Lukashenka's pro-Soviet narrative did not find acceptable political support in Russia. The possible impasse of nation-building politics forced the Lukashenka regime to reconsider its national narrative by broadening it in terms of recognizing the Belarusian pre-Soviet past and its importance for modern Belarusian identity. Thus, starting with 2002 it is possible to see a certain shift in the official rhetoric with regard to the Belarusian historical past, as well as the roots of Belarusian nationhood.

\section{Belarusian Identity Discourse 2002 - present}

Belarus's post-2002 identity discourse represents a broader understanding of Belarusian identity, going beyond a sole focus on state actions and its nation-building politics. Identity discourse also focuses on various expressions of official and alternative national narratives conducted by NGOs, represented in media or public initiatives, and expressed in public symbols such as monuments, street names, or promoted by music and cultural groups.

It seems that before 2002 neither Western, nor regional scholars had engaged in a debate over various expression of Belarusian nationalism. In 2003, Grigory Ioffe outlined two visions of Belarus, one having a Western orientation and the second - a pro-Moscow one. Later, in 2007 Ioffe added a third model of Creole nationalism that found its expressions in the nation-building policies expressed by the Lukashenka regime after 2002, as well as in the version of the Belarusian language that is called "Trasianka." Although "Trasianka" is a mixture of Belarusian and Russian languages, Ioffe claims that 
many people who speak it today are quite patriotic and nationalistic. ${ }^{133}$ Furthermore, it is vital to understand that there is also a Russian-speaking anti-Lukashenka group and not just Belarusian-speaking anti-Lukashenka groups. Thus, the opposition to Lukashenka's national narrative is not based on language distinctions only. There are, moreover, two more versions of Belarusian language: "Tarashkevitsa" and "Narkamawka" that might be assigned to different expressions of Belarusianness, however, they are less relevant for this research because they are not attached to particular expressions of Belarusian identity as "Trasianka" is. ${ }^{134}$

Nowadays, scholars tend to distinguish between various models of Belarusian nationalism rather than to focus on Belarusian post-Soviet national development per se. Nelly Bekus, for example, distinguishes between the official Belarusianness that is based on civic identity and alternative Belarusianness that is based on an ethnic definition. ${ }^{135}$ By doing so, Bekus incorporates smaller models into two broader categories. Analysis by Renee Buhra supports Bekus's claims that the official narrative is based on civic characteristics of Belarusian nation, and the alternative on ethnic identity. Furthermore, she argues, Belarusian national identity is gravitating towards a form of civic nationalism rather than ethnic nationalism. ${ }^{136}$ In a similar way, Andrew Wilson in his book Belarus: the Last Dictatorship in Europe distinguishes between the official and alternative identities facilitated by Lukashenka and by the political opposition. ${ }^{137}$ Wilson, however, distinguishes another approach towards Belarusian nationalism - the nation-in-between -, which claims that the real key to Belarusian history lies at the crossroads of

\footnotetext{
${ }^{133}$ Ioffe, Culture Wars, 365-366. "Trasianka" is a version of Belarusian language that is phonetically Belarusian and lexically Russian. "Trasianka" literally means: low-quality hay, or diluted with straw. It has a Belarusian grammatical base but uses Russian words and forms.

${ }^{134}$ Wilson, 124.

${ }^{135}$ Bekus, European Belarus, 280.

${ }^{136}$ Renee L. Buhra, Victor Shadurski and Steven Hoffman, "Belarus: An Emerging Civic Nation?" Nationalities Papers 39, 3 (May 2011): 437.

${ }^{137}$ Wilson, 139.
} 
many cultures and thus Belarus is a cross-cultural place where various nations and cultures interact without really emphasizing European or Russian dominance. ${ }^{138}$

Another scholar, Natalia Mamul claims that there are four post-Soviet templates: pro-Russian (imperialist) narrative, the victimized negative ethnic template, the Belarusian nationalist narrative and the pro-Western/pro-democratic scheme. ${ }^{139}$ The Belarusian researcher, Yuliya Chernyavskaya goes further and identifies seven, of what she calls competing temptations of Belarusian nation-building. ${ }^{140}$ Her analysis outlines seven possible nation-building choices that the Belarusian nation is experiencing at present in terms of its prospective development.

In 2002, however, the official national narrative began to be transformed and the transformation is visible in Lukashenka's speech that he gave at the Brest National University of A.S. Pushkin on September 23, 2004. Lukashenka claimed:

(...) Belarus, in distinction from Poland and the Baltic Countries, has never, I dare to say, never ever, has it been a part of Western culture and Western, especially Western way of life. Yes, we were subjected to the influence of the Western culture and its way of life, moreover - the Polish Lithuanian Commonwealth (Rzeczpospolita) and the Grand Duchy of Lithuania - all this has left a mark on us. That influence, however, is already gone. Because back then it failed to "sew on" everything Western on us, however, it seems that it will fail also today. ${ }^{141}$

\footnotetext{
${ }^{138}$ Wilson, 137.

${ }^{139}$ Natalia Mamul, "Narrative Templates of Post-Soviet Identity in Belarus" Polish Sociological Review 166 (2009): 231.

${ }_{140}$ Чернявская, 397-401. The first temptation is the temptation of the "closed door," second - uniformity of "civic-national body," third - identification of Belarusian with Belarusian-speaking, fourth - identification of "Belarusianness" with only one of its edges (or periods), fifth temptation is twofold, i.e. on the one hand is claims that the true people are only the "common people," but on the other hand it claims that the true people are "we" and "people like me." Sixth - attraction to the past, perception of Belarus in archaic tones. Seventh - "temptation of no protrusion."

${ }^{141}$ From the record of Alyaksandr Lukashenka's speech in front of the student youth of Brest, September 23, 2004, President of the Republic of Belarus www.president.gov.by, available: http://www.president.gov.by/ru/news ru/view/stenogrammavystuplenija-pered-studencheskoj-molodezhjju-brestchiny-5916/
} 
In this statement, first of all, the President recognized the influence of Western culture on Belarusian history, and second, he recognized the influence that the Grand Duchy of Lithuania had on Belarusian history and the nation in general. This statement also represents the Creole version of the official national narrative that would emphasize the Belarusian Soviet past together with the recognition of rich Belarusian pre-Soviet and pre-Imperial history. The Creole national narrative also recognizes the influence that Europe had on Belarus's past. Since after 2002 Lukashenka no longer sought political integration with Russia, it allowed him to pursue more constructive dialogue with the European Union. In 2004, the European Neighborhood Policy was developed to include also Belarus in order to avoid the emergence of new dividing lines between the actors. Today, even though Belarus remains outside most of the Policy's structures, it is highly possible that more fruitful cooperation will develop which would likely coincide with the official national narrative's greater recognition of the importance of Belarus's European past.

The aforementioned existence of different conceptualizations of Belarusian nation-building models signifies that Belarusian official nation-building policies are contested by different possible expressions of Belarusian national identity as identified by scholars based on their research. Of course, nation-building policies in any country can hardly satisfy the vision of every interested group. However, is seems that in Belarus there are more alternative groups in the Belarusian public sphere that express other national values and promote different memory from the one promoted by the official narrative. These groups vary from musical bands to reenactment groups and to groups of public officials in Belarusian centers other than Minsk.

In 1999, when Lukashenka's idea of unification with Russia was still on the agenda, a band called Stary Olsa (Стары Ольса) was formed. ${ }^{142}$ The band claimed to play medieval Belarusian music on medieval Belarusian music instruments. The band's goal was the most precise reconstruction of

\footnotetext{
${ }^{142}$ A band of medieval Belarusian music Stary Olsa, available: http://staryolsa.com/rus/dasje.html
} 
musical traditions of the Grand Duchy of Lithuania. Furthermore, the group has several songs that make direct claim to the Grand Duchy, for example, “Літвін," (Litvin) "Песня пра Вітаўта," (Song about Vytautas) and "Бітва пад Вориай" (The battle on Vorsha). Thus, the band clearly represents an alternative national narrative of Belarus, one that claims that the Belarusian nation has distinct historical roots in the Grand Duchy of Lithuania. This narrative, however, is also seen in the Creole official narrative that recognizes the importance of Belarus's pre-Soviet past in contemporary nation-building politics.

Another expression of the alternative national narrative found its way in Belarusian reenactment groups, which have reproduced historic battles, tournaments and events from the Belarusian past and primarily from the time of the Grand Duchy of Lithuania. For example, the medieval military history club, the Duke's Order (Княжы Гуф), which was established in 1999, focuses on the studying of the Grand Duchy of Lithuania, Rus' and Žemaitija in the fourteenth and fifteenth centuries together with recreating the attire, ornaments and households of that period. ${ }^{143}$ Primarily, such groups focus on the reconstruction of such notable medieval battles as the Battle of Grunwald or of Vorsha; however, they also imitate the daily life of medieval knights. Such practices clearly identify the Belarusian historical past with the European tradition, as well as the "golden" period of Belarusian history. Furthermore, such groups are not rare in their quantity; overall in Belarus there are dozens of such reenactment groups. In 2000, five reenactment groups from various Belarusian cities created the association of the "Knights of the Grand Duchy" (Рыцары Вялікага Княства), thus connecting these groups to the medieval Belarusian past of the Grand Duchy of Lithuania.

Therefore, musical bands and reenactments groups by their repetitive practices not only emphasize the alternative national narrative of Belarusian nationhood, but also reject the official national narrative of 1995-2002 when Belarusian historical roots were seen in the Soviet past. This rejection,

\footnotetext{
${ }^{143}$ Medieval History and Military Club the Duke's Order (Княжы Гуф), available: http://bel-knight.com/club/index.php
} 
however, is rather unintentional from the side of the reenactment groups because they do not carry any political narrative behind their practices. Therefore, the rejection is rather symbolic since they simply recreate practices that are linked to the Belarusian medieval past and which are not recognized in the state-promoted collective memory of the official narrative.

The government, however, could not ignore the symbolic rejection of the official narrative by the reenactment groups. The extended geography of the reenactment festivals together with the mass character of the events prompted a response by the government since the reenactment groups openly spread the alternative vision of the Belarusian historical roots. Thus, the authorities used similar ideas and practices of the reenactment groups to revive memories of the Second World War. ${ }^{144}$ To symbolically commemorate the Minsk defenders, on June 30, 2005 a historical and cultural complex, the "Stalin line," was opened that supposedly reconstructed a chain of defensive installations that were built from 1928 until 1939 under the direct order of Stalin in order to protect the Soviet Western border. The main problem, however, was that the Line was not as important as the memory presented about it. It was built west of Minsk in 1931-1932 to protect the interwar border of the Belarusian SSR and was in considerable disrepair when the Germans attacked in $1941 .{ }^{145}$ Thus, it appears that the modern "Stalin line" complex and the myth around it were invented to support the official narrative of Soviet and Belarusian heroic performance during the war. The invention of the "Stalin line," moreover, supports Eric Hobsbawm's approach to the invention of traditions by modern nation-states in support of some greater cause. In the Belarusian case, it is in support of the official Belarusian national narrative.

At this historical complex, however, a symbolic merger of the official and alternative narratives took place in 2007 when the complex proposed its property as the site for Belarusian Reenactors

\footnotetext{
${ }^{144}$ Bekus, Struggle over Identity, 257.

${ }^{145}$ Wilson, 139.
} 
Festival. ${ }^{146}$ Nelly Bekus claims that it created a historical continuity between the representation of medieval knights and more recent heroic events of the Second World War. Thus, Belarusian knights are presented as predecessors of the Great Patriotic War heroes who fought for the state in the twentieth century. Of course, such an interpretation is possible since Belarusian authorities wanted to produce a broader understanding of Belarusian national narrative by incorporating certain pre-Soviet aspects of Belarusian nationhood. Belarus further recognized the importance of reenactment groups and on February 19, 2008 an exhibition about the knights of the Grand Duchy of Lithuania was opened in the National Museum of History and Culture of Belarus. ${ }^{147}$

Today, the "Stalin line" has incorporated certain techniques used by the reenactment groups and on special occasions they organize reconstructions of certain battles of the Great Patriotic War. The last one took place on February 22, 2014 when the Complex organized several reenactments of battles together with performances by professional soldiers and war-dogs. ${ }^{148}$ Such practices clearly mark the similarity between the practices of the medieval reenactment groups that represent the alternative national narrative, and the twentieth-century reconstruction groups that represent the official national narrative. Thus, the official narrative not only merges with certain practices of the groups representing the alternative national narrative, but also invents myths about the Soviet and Belarusian heroic performance during the Second World War. Furthermore, it is not surprising that the representatives of the official narrative borrowed several practices from outside groups since the Belarusian government claims to be the repository of Belarusian sovereignty together with rights to represent the Belarusian state.

\footnotetext{
${ }^{146}$ Bekus, Struggle over Identity, 258.

147 «Рыцары Вялікага Княства» ў Менску, February 20, 2008, Наша Hiвa, www.nn.by, available: http://nn.by/?c=ar\&i=15178

${ }^{148}$ Military-athletic celebration in memory of soldiers-internationalists, the Day of Defender of the Fatherland and Armed Forces of the Republic of Belarus, February 22, 2014, Historical and Cultural Complex "Stalin line" www.stalin-line.by, available: http://www.stalin-line.by/140114.shtml
} 
Already in 2004 a presidential decree prohibited private Belarusian media from using the words "national" or "Belarus" in their names, thus claiming official authority over the Belarusian public sphere. Furthermore, social advertising with the motto "For Belarus" was introduced in 2004, also pointing to the link between the government and the word "Belarus." In 2005, it was prohibited to use the same words "national," "Belarus" and "Belarusian" in the names of public organizations. ${ }^{149}$ Such monopolization of the usage of words "national" and "Belarus" led to a relative conflict between the intentions of the youth political organization Malady Front to conduct their St. Valentine Day's political street actions under the slogan "I love Belarus" and the state monopoly of Belarusian public space in representations of Belarus. ${ }^{150}$ Malady Front's event had been taking place since 1997 and therefore Belarusian authorities could not ban it without a reasonable motive. Thus, on February 14, 2007 the progovernmental youth organization Belarusian Republican Youth Union conducted its own action under the slogan "For beloved Belarus." 151 This serves as yet another example when Belarusian authorities want to claim the state's monopoly over the representation of Belarus in the public sphere.

In general, since 2002 a greater focus on the consolidated Belarusian nation is seen in the Belarusian public sphere, which is centered on emphasizing Belarusian sovereignty and independence under the present political regime. After 2002 various public institutions acquired the status and the name "national," such as the Academy of Science, Minsk Airport II and the Central Historical Archive. Furthermore, the Supreme Soviet was renamed the "National Assembly." The new building of the National Library of Belarus began construction in November 2002 and was funded by public donations to make the project even more national. ${ }^{152}$ In addition, Belarusian towns acquired their personal coats of

\footnotetext{
${ }^{149}$ Wilson, 176.

${ }^{150}$ Bekus, Struggle over Identity, 167.

151 Белорусский Республиканский Союз Молодёжи БРСМ, www.brsm.by, Культурно-массовые мероприятия, «За любимую Беларусь», available: http://www.brsm.by/ru/proekt/Kult-masmeropr/za lub bel

${ }^{152}$ Leshchenko, 342.
} 
arms designed by the Council of Heraldic Affairs under the presidential administration. Thus, towns at the local level also acquired the new Belarusian identity.

Nationalization of the words "Belarus" and "nation" in public discourse was only one expression of Belarus's post-2002 nation-building policies. The situation was necessarily changed also in Belarus's linguistic policies. According to 2005 polls, in response to the question about native language and mother tongue that Belarusian people used, 34.6 percent claimed Russian as their native language in comparison to 30.7 percent who claimed Belarusian as their native language. ${ }^{153}$ The situation, however, was completely different with regard to mother tongue of respondents. 69 percent indicated Russian as their mother tongue in comparison to 6.6 percent who indicated Belarusian as their mother tongue. ${ }^{154}$ According to this data, the author concluded that Belarusian language served as a "badge of ethnicity" rather than a practical language since Belarusians overwhelmingly used Russian as their mother tongue. It is worth mentioning that independent sociologists in 2006 have concluded that surveys are no longer possible to conduct in Belarus due to poor conditions that the state has created for the recording of opinions. ${ }^{155}$ Thus, the previously mentioned data from 2005 appears to be more reliable for this research than what has been generated after that date.

The nation-building process, however, is not an official/governmental process only; the role of intelligentsia, of a country's national and cultural elites, is also recognized as an important factor in a nation's self-imagination and self-determination. Thus, it would also be worth analyzing opinions of the Belarusian elites; however, a study from 2006 concluded that Belarusian elites together with the counter-elites had only started to look for answers to questions about where and whom Belarusians

\footnotetext{
${ }^{153}$ Mother tongue is considered to be the language that people have been speaking with their mother since childhood.

${ }_{155}^{154}$ Anthony Brown, "Language and Identity in Belarus" Language Policy (2005): 322.

155 Беларусь: ни Европа, ни Россия. Мнения белорусских элит, Под редакцией Валера Булгакова (Варшава: Издательство "ARCHE," 2006), 7.
} 
should be. ${ }^{156}$ In this regard, because Belarusian elites are weak in terms of defining the nation-building process, it seems that the government can occupy the primary role of defining one in their place. In 2010, however, Belarusian researcher Yuliya Chernyavskaya concluded that Belarusians have already completed the transformation from identifying themselves as locals (тутэйшасиь) to the point where they started identifying themselves as being Belarusians. ${ }^{157}$ Her conclusion was drawn from the idea that the concept of "mутэйшасиь," which described the locality of the peasant as his homeland, had given way to describing Belarus as the homeland. It would be hard to see the role of the government in facilitation such an understanding; however, it seems that Belarusian symbols and the government's post-2002 rhetoric played a significant role in developing Belarusian understanding of self-identification within the region. Furthermore, the government played a role of mediator between the idea of Belarus's sovereignty and independence, and people's imagination of being Belarusian.

Chernyavskaya also concluded that, paradoxically, people (online bloggers in particular) thought about being a part of unified Europe, with self-identification as "mутэйшасиь" - being reserved, mentally "separated," or principally detached from other regional nationalities. ${ }^{158}$ Such identification, according to her, creates an obstacle for Belarus on its way to becoming a part of unified Europe. ${ }^{159}$ In this regard, it is reasonable to think about the European Union (EU) and Europe in general as an influencing factor in the Belarusian identity development process.

Indeed, in 2009 Belarus became a part of the Eastern Partnership initiative of the EU within the European Neighborhood Policy. In terms of this initiative, the EU's assistance focuses on supporting the needs of the population, directly and indirectly supporting democratization and mitigating the effects of

\footnotetext{
${ }^{156}$ Ibid., 22.

157 «Культуролог Чернявская: Путь от «тутэйшых» к нации белорусы уже прошли» Маrch 23, 2010, Белорусский партизан, www.belaruspartisan.org, available: http://www.belaruspartisan.org/life/158526/

158 Чернявская, 376.

${ }^{159}$ Ibid, 388.
} 
the self-isolation of Belarus and its society. ${ }^{160}$ During the Vilnius Summit in November 2013 it was agreed that Belarus would continue negotiations with the EU on a visa liberalization program; however, the situation has not yet improved. Notwithstanding, Belarus-EU relations support the alternative national narrative's claims of Belarus's historical ties with Europe. As long as the formal cooperation with the EU persists, it is possible to claim that Belarus and its society's connection to the EU support the alternative national narrative that exists in Belarus. The EU-Belarus bilateral cooperation, however, has been developing only "on paper" rather than in terms of actually achieved results. Nowadays, Belarus participates in the Eastern Partnership only in its multilateral track rather than directly with the EU. ${ }^{161}$ Thus, in terms the European Neighborhood Policy and Eastern Partnership initiative, Belarus remains outside the EU's main cooperation policies that are directed at establishing closer dialogue with Belarus. The existing situation, on the other hand, may signal that the official national narrative in Belarus continues to see its pro-Russian direction as more important than a pro-European one in defining Belarus's identity.

In the post-2002 period, when the official regime started recognizing the influence that Belarus's medieval past had on the modern state of Belarus, expressions of the alternative national narrative started to find support in various public initiatives in Belarus. In 2009 the local administration of the city of Navahrudak proposed to erect a monument to the creator of the Grand Duchy of Lithuania - King Mindaugas. The Ministry of Culture of Belarus supported the idea in 2012, but the initiative has remained on the level of intentions. Nevertheless, the memory of Mindaugas in Navahrudak is recognized by the "Mindaugas' Hill" where his body is buried according to the legend. ${ }^{162}$ Even though there are no monuments of King Mindaugas, some other monuments had been erected. For example, a

\footnotetext{
160 European External Action Service, www.eeac.europa.eu, EU Around the Globe, Belarus, available: http://eeas.europa.eu/belarus/index en.htm

${ }^{161}$ Ibid.

162 Экскурсии по Беларуси, www.ekskursii.by, Гора Миндовга, available: http://www.ekskursii.by/?exkursobj=2576
} 
monument of Vytautas stands in the city of Grodno; in 2010 another monument to Vytautas was opened in the village Pelesa, Grodno Oblast'. A monument to Grand Duke Gediminas was proposed to be erected in the city of Lida that is also located in Grodno Oblast'. Despite such public and local initiatives, they lack governmental support in financial terms. Even though the government and ministries support such initiatives, they often tend to postpone the actual financing of monuments as in Navahrudak. ${ }^{163}$

The most symbolic break with the pre-2002 official narrative, however, is seen in the city of Grodno where a commemorative composition is scheduled for construction on the place where a Catholic Church, built by the order of the Grand Duke Vytautas, was destroyed by the Communist regime on November 29, 1961. ${ }^{164}$ In this regard, such an initiative goes against the official pre-2002 narrative of favoring the Soviet period. As occurred following the discovery of mass graves in Belarus in 1988, the Soviet regime is condemned for destruction of the Belarusian pre-Soviet national heritage. The post-2002 national narrative, therefore, includes intentions to rebuild the pre-Soviet architecture, thus supporting the alternative narrative of Belarus's historical connection with Europe.

Similar intentions are represented in private initiatives to preserve visual memory of pre-Soviet architecture in Belarus. The webpage Belarusian Globe seeks to preserve architectural and other landmarks of Belarus. Its primary goal is to collect photographs of all pre-1917 landmarks for Eastern Belarus, and pre-1939 landmarks for Western Belarus. ${ }^{165}$ In 2011, 10,600 such objects were found and photographed in Belarus. The idea of the initiative is to preserve the pre-Soviet heritage of Belarus, thus emphasizing the alternative narrative of Belarusian historical past. The initiative, however, refuses to

\footnotetext{
163 «Беларусам не нужен памятник Миндовгу» November 20, 2012, Беларусский Партизан, www.belaruspartisan.org, available: http://www.belaruspartisan.org/life/223395/

164 «В Гродно на месте снесённой 52 года назад Фары Витовта появится памятный знак» December 2, 2013, Блог Гродно s13, www.s13.ru, available: http://s13.ru/archives/70569

165 «Глобус Беларуси», Архитектурные и иные достопримечательности Беларуси, available: http://www.globus.tut.by/index.htm
} 
recognize only the Soviet past by accepting the era of the Russian Empire in its periodization. Such an idea, even though at odds with the pre-2002 official national narrative, may support the post-2002 national narrative in which the Belarusian pre-Soviet heritage is recognized.

In Belarusian public and cyber space even more alternative expressions of the Belarusian national narrative may be found. Today, the Internet provides better options for unrecognized alternative groups to express their ideas with regard to the Belarusian historical narrative. The most visible among such groups is the Litvania community that actively promotes the idea of Litvins as the ancient people of Belarus. The Belarusian nation, on the other hand, is considered a Russian-created nation that emerged in the nineteenth century. Therefore, Litvins and Belarusians are two different nations with different meanings, according to Litvania. ${ }^{166}$

The recreation of the Litvin nation was proclaimed on May 20, 2000 when the first Litvin activists signed the Act of Proclamation of the Litvin nation. Litvins are presented as a liberal nation that stands for inclusion of the Belarus, Ukraine and Russia into the European Union. According to their beliefs, Litvins and Belarusians are different nations in terms of their cultural, historical and mental contexts; however, any person can become a Litvin if that person experiences the necessity to become one. The Litvin nation is considered a liberal, "open nation" with religious, linguistic and national tolerance. ${ }^{167}$ The group's historical position is that the Old Litva disappeared with the creation of the Belarus Soviet Socialist Republic and therefore modern Lithuanians were able to assign the name "Lithuanians" to themselves.

This alternative narrative is based on an interpretation of historical events that is closely related to fiction since this narrative is recognized only by Litvins themselves. When looking at their official name, however, we see that sometimes the concept of Litvins is used in the official national narrative

\footnotetext{
${ }^{166}$ The official webpage of the Litvin movement, available: www.litvania.org

${ }^{167}$ Ibid.
} 
presented in Belarusian history textbooks when referring to inhabitants of the Grand Duchy of Lithuania. Even though the Litvania interpretation of the region's history should not be treated seriously, it is important for this research to recognize it as an existing alternative narrative to the official national perception of Belarusian historical identity.

Despite the existence of visible representations of the alternative national narrative, the Belarus government does not want to go beyond the recognition of the pre-Soviet past in terms of its influence on Belarusian culture and characteristics. For example, on the sixtieth anniversary of the Soviet victory in the Second World War in 2005, Francysk Skaryna Avenue was renamed Independence Avenue. ${ }^{168}$ Thus, the avenue that previously was named for the Belarusian sixteenth-century publisher and enlightener was renamed to represent the pro-Soviet narrative of recognition of Soviet deeds. It showed that the Soviet values were still treated seriously, especially the Second World War memory and its sacralization. According to the Belarusian pro-government analyst Lev Krishtapovich (Лeв Криштапович), the past of the Grand Duchy of Lithuania has nothing to do with the Belarusian nation. More precisely, on March 15, 2012 the vice president of the Information and Analytics Center under the President's Administration claimed that intentions to claim the existence of Belarusian identity from the period of the Grand Duchy of Lithuania have nothing to do with the real process of spiritual strengthening and overall development of Belarus. ${ }^{169}$ Therefore, it is possible to conclude that the process of inclusion of the pre-Soviet past into the official national narrative requires broader public debate involving representatives of alternative narratives. This process, nevertheless, does not seem feasible in the near future due to the undemocratic character of the present Belarusian government.

\footnotetext{
168 Yaroslav Shimov, "Belorussia: Vostochnoevropeiskii paradoks" Neprikosnovennyi zapas 3, 47 (2006),http://magazines.russ.ru/nz/2006/47/sh11.html

169 «Лукашисты предлагают вычеркнуть ВКЛ из истории Беларуси» March 15, 2002, Хapтыя'97, www.charter 97.org, available: http://charter97.org/ru/news/2012/3/15/49337/
} 
Alyaksandr Lukashenka, as an undemocratic president, however, has become strong in his rhetoric that would exemplify the post-2002 modification of the official national narrative. On April 22, 2014 during his state of nation address, Lukashenka claimed that in light of the events in Ukraine, it was necessary to protect a precious value - the independence of Belarus. ${ }^{170}$ This statement goes against the 1995-2002 official narrative when Belarusian independence was rather deemphasized, and closer political and economic integration with Russia was promoted. Therefore, the post-2002 rhetoric of Belarus's independence and sovereignty is also influencing Belarus's geopolitical choices in terms of East or West. On April 22 Lukashenka said that he would not sign the founding treaty of the Eurasian Economic Union unless all limitations and exemptions for the free trade regime are removed. ${ }^{171}$ Lukashenka claimed that if all limitations on the free trade were lifted only fifteen years after the treaty is signed, then he also would sign the treaty only in fifteen years. Therefore, such rhetoric is completely opposite to the warm and pro-Russian rhetoric of the late 1990s. The aforementioned example of the Belarus's president's changing attitude towards integration with Russia means that the official national narrative of the Lukashenka regime is changing and is also dependent on the domestic discourse over the Belarusian nation-building process.

This study's post-2002 Belarusian identity discourse analysis has shown that today there are various expressions of Belarusian identity in the public sphere that can be categorized between the official and alternative national narratives. These narratives differ in their interpretation over which historical events should be considered foundational events in the development of Belarusian nation. Medieval reenactment groups, musical bands, monuments, use of the Belarusian language on national level etc. promote the alternative national narrative. The official national narrative, on the other hand, is promoted via state symbols and state-sponsored historical memory that is visible in the example of the

\footnotetext{
${ }^{170}$ Yauheni Preiherman, Lukashenka's State of The Nation Address: Top 5 Messages, April 24, 2014. News Agency www.belarusdigest.com Available: $\underline{\mathrm{http}: / / \text { belarusdigest.com/story/lukashenkas-state-nation-address-top-5-messages-17618 }}$ ${ }^{171}$ Ibid.
} 
"Stalin line" complex. Furthermore, the official narrative is spread via the nationalization of Belarusian public space by the government through the ban on non-governmental use of words "Belarus" and "nation." Therefore, the domestic identity discourse and change in nation-building policies since 1990s has directly affected Belarusian political representation within the region. 


\section{CHAPTER THREE: CONTESTED HISTORY AND MEMORY IN}

\section{BELARUSIAN HISTORY TEXTBOOKS}

The post-Soviet Belarusian nation-building process started after an independent Belarus was proclaimed in 1991. Moreover, it is possible to see patterns of the nation-building process conducted through public education in modern Belarus similar to the nation-building experience of the nineteenth-century European states. This chapter focuses on history textbooks, which are currently in use in Belarusian public schools with the Russian as the language of instruction. History textbooks published in the years 2009 and 2010 can be viewed as a product of the Belarusian national project first mentioned by the President Lukashenka in 2002 and later implemented through official documents in 2003-04 and 2006. ${ }^{172}$ Furthermore, state history textbooks contain the values and standards of the Belarusian government as outlined in the Educational Standard of the Subject "World History. History of Belarus" (5-11 grades), and The Concept of Subject "World history. History of Belarus." 173 In order to comprehend the essence of the official Belarusian national narrative in history textbooks, it is necessary understand these documents.

\footnotetext{
${ }^{172}$ As outlined in the introduction to this research, see an Order from 2003 of the Ministry of Education "On Ideological Guidance of Educational Work," "The National Strategy of Stable Social-Economic Development of the Republic of Belarus until 2020" accepted in 2004 and the "General vectors of social-economic development of the Republic of Belarus for 20062015 " accepted in 2006.

${ }_{173}$ Министерство Образования Республики Беларусь, “Образовательный стандарт учебного предмета "Всемирная История. История Беларуси" (5-11 классы),” №. 32, Мау 29, 2009, and “Концепция учебных предметов - “Всемирная история. История Беларуси” №. 675, Мау 29, 2009.
} 


\section{The Belarusian National Narrative in Legal Documents}

The Republic of Belarus officially recognizes the effects that globalization has on the process of the study of history in Belarus. ${ }^{174}$ This acknowledgment of the internationalization of education shares Andy Green's assumption that due to the growing effects of globalization governments will nevertheless try to promote a country's national identity by recognizing the complexity of multiethnic networks, which have affected that identity. ${ }^{175}$ Since Belarus exists in close proximity to other regional actors, it is necessary for Belarus to emphasize its tolerance and relationships with people of other nationalities. Such an acknowledgment also corresponds to Andy Green's model of internationalization of education due to the interconnectivity of a shared past. Education in Belarus is used as a basis for the promotion of nationhood and national consciousness at a time when Belarusian nationhood is still under construction. Even though the history subject is called "World history. History of Belarus," this research primarily focuses on the "History of Belarus" as the major facilitator of the Belarusian national narrative in schools.

Historical education in secondary schools is seen as means for promoting a sovereign Belarusian state, civic consciousness, patriotism and national consciousness among the pupils. ${ }^{176}$ Moreover, historical education is seen as key to historical memory and historical consciousness formation. Historical memory promoted by state institutions and services appears to be a governmentally mediated memory as it develops within a certain society. In the Belarusian case greater attention toward historical education highlights its importance to identity formation since education is seen as a promoter of civic consciousness and tolerance towards regional nations and cultures for Belarusian pupils.

\footnotetext{
174 Министерство Образования Республики Беларусь, “Концепция учебных предметов - "Всемирная история. История Беларуси” №. 675, Мау 29, 2009.

${ }_{175}$ Andy Green, Education, 5.

176 Министерство Образования Республики Беларусь, “Концепция учебных предметов - “Всемирная история. История Беларуси” №. 675, Мау 29, 2009.
} 
An important aspect of The Concept of Subject "World history. History of Belarus" is the existence of direct intentions to use historical education in the establishment and promotion of the official Belarusian national narrative. More precisely, historical education forms national identity of Belarusians that is defined as the concrete emotional-psychological, politico-ideological and cultural composition of personality which reveals itself in the process of self-perception and self-identification within the surrounding world from the point of view of a representative of Belarusian nation which has deep historical roots. ${ }^{177}$

Historical memory in the legal documents is understood as the ability to appreciate the historical traditions of Belarusian people, but defined as all forms of information about the events of the past, their time and space, as well as the participants in those historical events. ${ }^{178}$ The inclusion of historical memory among the goals and objectives of Belarusian historical education is definitely a good incentive; however, the theoretical framework of this research showed that both memory and traditions can be either constructed or invented for various purposes. This means that the establishment of historical memory is a complicated process of national narrative building that requires a dialogue between both state and society in order to produce a satisfactory narrative for the greater part of society that would actually legitimize the narrative itself. In the case of Belarus, however, such dialogue is rather infeasible since the government tries to secure its authority over the Belarusian state and nation in which the production of historical/political memory, as well as the invention of traditions, becomes a biased, topdown process reflecting solely the state's vision of the national narrative and excluding larger perceptions of alternative Belarusian national narrative promoted by the opposition and non-state actors.

National consciousness is officially defined as an awareness of belonging to the modern Belarusian nation, that is, a political nation with the defining principle of the existence of a sovereign

\footnotetext{
177 Министерство Образования Республики Беларусь, “Концепция учебных предметов - "Всемирная история. История Беларуси” №. 675, Мау 29, 2009.

${ }^{178}$ Ibid.
} 
Belarusian state ${ }^{179}$ In the aforementioned definition two concepts are noteworthy for an understanding of the official national narrative. First, the use of "modern" while addressing the Belarusian nation emphasizes the official position of the Lukashenka government, which tries to separate the pre-Soviet or even pre-Russian past from the medieval past of Belarusian nation. This distinction is necessary for the legitimacy of the government as the sole representative of the modern Belarusian nation, which, moreover, inhabits a sovereign state. In this regard, the distinct historical roots of Belarusian nation are less important than the acknowledgment of the present Belarusian nation, which has incorporated various pasts to become modern, independent and sovereign in the present.

In the subject "World history. History of Belarus," pupils have to cover a broad range of social, economic, political, legal and other aspects of the Grand Duchy. Of course, the period starts with a discussion of the formation of the Grand Duchy. Later, however, it proceeds to the questions related to the formation of Belarusian nationhood. It is important to notice that the Educational Standard is treating the Grand Duchy of Lithuania separately from the understanding of Belarusian lands. For example, such topics as the cultural life of Belarusian lands and "Our region (kray) in the mid-thirteenth century and first half of the sixteenth century" are treated independently from the Grand Duchy of Lithuania. ${ }^{180}$ Starting with the middle of sixteenth century, topics on the Grand Duchy of Lithuania attempt to show its relative independence as part of the Polish-Lithuanian Commonwealth. On the one hand, this approach points to the existence of double standards in the official treatment of the Grand Duchy of Lithuania; on the other hand, it fits into the official narrative of emphasizing a distinct past of Belarusian people.

\footnotetext{
179 Министерство Образования Республики Беларусь, “Концепция учебных предметов - “Всемирная история. История Беларуси” №. 675, Мау 29, 2009.

${ }^{180}$ Ibid.

"Nash Kray" is a more sentimental and personal approach to call a native region that is historically connected to one nation.
} 
The examination of legal documents reveals structural patterns of the official Belarusian national narrative that are supposed to be visible in the 2009/2010 Belarusian history textbooks. The contents of the Concept and the Standard of historical education in Belarus bear a striking resemblance to the official model of Belarusian national narrative. Therefore, it is now possible to focus on the textbooks themselves to evaluate the hypothesis whether the Belarusian national narrative is challenging the Lithuanian national narrative in Belarusian history textbooks. To make the analysis theoretically stronger, however, it is necessary to review the existing research made on Belarusian history textbooks in order to have better understanding of possible patterns of Belarusian-Lithuanian representation within the period of the Grand Duchy of Lithuania.

\section{Existing Research on Belarusian History Textbooks}

Despite the topicality of Belarusian history in local and regional mass media, there is an evident absence of academic research on the narratives of Belarussian history presented in Belarusian history textbooks. Every time a new book on Belarusian history is released it motivates a debate and thus attracts greater attention to the topic of Belarusian history and the question of the particular narrative discussed in the book. It seems that media analyses, however, are adequate to satisfy the public's interest in how the Belarusian government and historians interpret the state's history. Usually, such media accounts address the problem of rewriting Belarusian history in history textbooks in terms of their effect on the comprehension of Belarusian history in general. ${ }^{181}$ Media commentary describing the negative connotations of rewriting of Belarusian history is especially visible among more independent media such as Charter '97. Also the Russian media engages in history textbook analysis, usually to portray that

181 Charter '97, “Учебники по истории Беларуси переписали (фото)” August 21, 2009, Available: http://charter97.org/ru/news/2009/8/21/21280/ 
Belarusian textbooks have interpreted some particular past with positive or negative connotations in regard to Russia. ${ }^{182}$ Such analyses appear negative in addressing Belarusian nationhood and its independent historical roots. Sometimes media agencies analyze Belarusian history textbooks in terms of a broader discussion of textbooks in the Commonwealth of Independent States (CIS) or textbooks in an even larger region. ${ }^{183}$ Such examples that incorporate the study of regional textbooks, however, show that one nation's history cannot be treated separately from other regional actors and therefore, it is vital to acknowledge their presence and possible importance in nation-building.

Several scholars have analyzed Belarusian history textbooks in various details. Nelly Bekus discusses differences between official and alternative narrations in Belarusian history textbooks in the chapter within her larger research on the Belarusian struggle over identity. ${ }^{184}$ Her understanding of the Belarusian national narrative is also divided into the two categories of official and alternative. According to her conclusions, the main difference between the two types lies in geopolitics and the treatment of Russia as the "other" because the official narrative sees Russian influence in the region as a positive aspect for Belarusian nationhood but the presence of the Grand Duchy of Lithuania in Belarusian history - as negative. The alternative narrative sees both periods oppositely, highlighting the Grand Duchy and diminishing the Russian influence. ${ }^{185}$

Even though Nelly Bekus incorporates some of the official textbooks in her comparative analysis, her goal is not to research the textbooks per se, but rather to compare official historical

\footnotetext{
182 News Agency Regnum, «Становление поневоле»: проблема формирования белорусской нации в школьном курсе истории Белорусии, January 14, 2014, Available: http://www.regnum.ru/news/polit/1754078.html

${ }_{183}$ See for example: Informational and Analytical portal "Nasledie," "Распад СССР в школьных учебниках: России, Украины, Беларуси, Латвии, Киргизии, Таджикистане, Кахазстана, Армении, Грузии, Молдавии и Германии," August 20, 2013, Available: http://nasledie.ru/?q=node/2314 and Russian BBC Service, "Белоруссия: как пишут учебники истории," $\quad$ November 6, 2013, Available: http://www.bbc.co.uk/russian/international/2013/11/131028 history textbook belarus.shtml

${ }^{184}$ Nelly Bekus, "Belarusian History: The Alternative and Official Historical Narrations" in Struggle Over Identity. The Official and the Alternative "Belarusianness" (Budapest: Central European University Press, 2010), available: http://books.openedition.org/ceup/581

${ }^{185}$ Bekus, 180.
} 
narration in textbooks with more alternative interpretations in non-governmental publishing. This approach is different from the media analyses since media agencies try to use a diachronic approach and analyze different textbooks' interpretations taken from different years. Bekus, however, does not explain her choice of textbooks and uses them simply as an example of the official history interpretations. In this regard, she uses textbooks from various years - 2000, 2003, 2004 and 2005. All textbooks came from the schools or universities with Russian as the language of instruction and, at the time her book was published, new history textbooks were introduced and had already been in use in Belarusian schools.

After analyzing two historical narratives presented in official textbooks and books on Belarusian history in free circulation, Nelly Bekus concluded: "Historical discourses serve as a basis for a certain concept of Belarusianness; formulations and definitions of this concept can be found in political discourses, where the national idea is articulated on the material of historical presentations of the Belarusian past." ${ }^{186}$ According to Bekus, the official narrative presented in history textbooks is a part of political discourse that, in the end, is able to produce a certain understanding of what "Belarusianness" means for Belarusians. The work extracts the official narrative from the textbooks and puts it into the larger discussion of "Belarusianness" that exists in the Belarusian public sphere.

In contrast to Bekus's approach, Belarussian researcher Tatyana Ostrovskaya compares different historical narratives and interpretations within Belarusian history textbooks in order to better see the change of narratives according to particular periods since 1991. Ostrovskaya analyzes Belarusian history textbooks published from 1993 to 2009 in order to overview the basic phases of (re)construction of national historical memory within the boundaries of the education system, with its possible influence on national identification. ${ }^{187}$ Among the outcomes of her research, Ostrovskaya identifies three distinct periods in history textbooks where the narrative of textbooks significantly changed. The first period of

\footnotetext{
${ }^{186}$ Bekus, 196.

${ }^{187}$ Островская, 2.
} 
1993 - 1995 she called an anti-colonial period during which the process of deconstruction of Soviet/colonial myths took place. The second period began in 1996 soon after President Lukashenka took office and ended in 2001 when the President's office reconsidered its national policies. This period was characterized by an increasing struggle with the existing national project of that time. The third period started with 2002 and concluded with the end of her research in 2009, and is marked by the intentions of Lukashenka's government to construct a new history, i.e. a new national idea. ${ }^{188}$

The third period is of the most significant interest not only for the present-day nation-building policies of Belarus but also for this research in particular. Ostrovskaya claims that the period started with Lukashenka's speech in 2002 when the President claimed that a national idea should be developed, but that the Belarusian nation was not fully ready for that. ${ }^{189}$ Undoubtedly, the claim by Lukashenka is important, however, there was another reason for Lukashenka's change of mind. Just before Lukashenka's speech in the summer of 2002, Russian President Vladimir Putin commented on the prospect of Russian and Belarusian unification into one state; he said that the only feasible route would be the incorporation of Belarus into the Russian Federation. ${ }^{190}$ Prior to this statement, Lukashenka had hoped for better conditions if Belarus and Russia were to merge into a single union. It is conceivable that after the summer of 2002 Lukashenka saw Belarusian sovereignty as a sole guarantee of his power and security, and thus changed his policies in order to maintain Belarusian statehood and sovereignty. ${ }^{191}$ A strong Belarusian nation, however, was needed to maintain Belarusian integrity at that time. It meant that the national idea of Belarus would be able to unite people around their independent and sovereign state without intending unification with Russia in any possible form.

\footnotetext{
188 Островская, 35.

189 From the record of Alyaksandr Lukashenka's Press Conference held on September 17, 2002. Tut.by News agency. Стенограмма пресс-конференции Президента Республики Беларусь А.Г.Лукашенко 17 сентября 2002 г. http://news.tut.by/society/18153.html

${ }^{190}$ Leshchenko, 341.

${ }^{191}$ Ibid.
} 
The third period outlined by Ostrovskaya started in 2002. Now, Belarusians started to be characterized as Slavs, West-Russians and as Russian in general. ${ }^{192}$ In contrast with the second period, the post-2002 narrative has been characterized by the intentions of historians to accumulate pre-Soviet events of Belarusian history, establish a Belarusian ancient past, as well as find deeper roots of Belarusian statehood. ${ }^{193}$ Post-2002 textbooks, however, do not provide clear answers and representations of "Belarusianness." Only a clear connotation of state ideology gets incorporated into the textbooks, claims Ostrovskaya. ${ }^{194}$

The most important conclusion in regard to this research is Ostrovskaya's observation that the narrative of Lithuanians in Belarusian history textbooks is presented without a clear evaluation - they are neither criticized nor described in general. It is emphasized, however, that during the period of the Grand Duchy of Lithuania the Balts occupied a lower level of development than the Slavs. ${ }^{195}$ Even though this conclusion is valuable for my research, it does not shed light on the intentions of Belarusian history textbooks to "rewrite" the Lithuanian past. Furthermore it is hard to say whether the Belarusian national narrative is somehow contesting the Lithuanian one.

Notwithstanding the use of the same history textbooks as I do in this research, Ostrovskaya does not focus on the Belarus-Lithuania narrative during the period of the Grand Duchy. Therefore, this research is able to complement existing scholarship on Belarusian history textbooks. In particular, it provides a greater understanding of how the Belarusian national narrative is trying to promote the creation of the Belarusian national idea on the particular example of Belarus-Lithuania relations during the Grand Duchy of Lithuania. Now it is necessary to turn to an overview of the research itself.

\footnotetext{
192 Островская, 6.

193 Ibid, 7.

194 Ibid, 36.

195 Ibid, 35.
} 


\section{Construction of the Official Belarusian National Narrative in Belarusian History}

\section{Textbooks}

In the period from 1995 until 2002, treatment of the inception of the Belarusian nation was linked with the first appearance of Slavic tribes in Belarusian lands. Belarusians were defined as Slavs, as WestRussians and, in the end, as Russians. ${ }^{196}$ Different interpretations still existed due to the lack of conceptual uniformity in Belarusian textbooks. Nevertheless, the official national narrative resembled the narrative, which existed during the Soviet era. In the post-2002 textbooks, the rehabilitation of the pre-Soviet and pre-Russian history topics of the Belarusian past becomes visible. This period marks the incentives to historicize the Belarusian nation together with an emphasis of the deep historical roots of Belarusian nationhood. ${ }^{197}$

History textbooks from 2009/2010 continue the idea of Belarusian nation's antiquity together with further interpretation of Belarusian ancestry. First of all, it is said that all Belarusian lands belonged to an Old Russian state with the capital in Kiev. It is also said, however, that Kievan Rus' was a common state of the so-called Eastern Slavs. ${ }^{198}$ This narrative of Eastern Slavs is extremely important and appears to be a new interpretation of the deep roots of Belarusian nation. On the one hand, Eastern Slavs are not precisely Russians, which leaves place for more distinct Belarusianness, but they are Slavs nonetheless. Such an interpretation combines Belarusians with other Slavic nationalities such as Russian and Ukrainian.

The sixth grade textbook provides a scientific explanation behind the Eastern Slavic community of the Kievan state, claiming that Eastern Slavic tribes had a lot of things in common, such as language,

\footnotetext{
${ }^{196}$ Ibid, 6.

197 Ibid, 7.

198 История Беларуси с древнейших времён до середины ХІІІ в. Учебное пособие для 6 класса под редакцией Г.В. Штыхова и Ю.Н. Бохана. (Минск: «Издательский центр БГУ», 2009), 79-80. Available at: http://slovo.ws/urok/historyofbelarus/06/001/001.html
} 
territory of habitation, culture etc. Furthermore, such a community is sometimes called an Old-Russian nation (друвнерусская народность), which became a common source for all three nations Belarusian, Russian and Ukrainian. ${ }^{199}$ In this regard, there are two crucial concepts for understanding the modern Belarussian interpretation of its nation's antiquity - Eastern Slavic tribes and a common OldRussian nation.

More than that, the main common denominator for the Old-Russian nation was language. The textbook mentions that such old-Russian sources as chronicles and stories testify that Eastern Slavs had one literary language. ${ }^{200}$ This implies that ancestors of modern Belarusians, Russians and Ukrainians spoke one language. At least on one occasion, textbooks mention that already in the medieval period some people spoke Belarusian. ${ }^{201}$ This is a strong conclusion for the textbook; however, it acknowledges that spoken languages differed among the people due to the great territorial spread of Eastern Slavic habitation.

The seventh grade history textbook continues the national narrative of Belarusians belonging to Eastern Slavs. More precisely, the authors claim: "If Kievan Rus' is called the cradle of Belarusian people, then the Grand Duchy of Lithuania marked the adulthood of Belarus."202 The Grand Duchy of Lithuania is mentioned as a political entity where the Belarusian nation had been formed. Furthermore, Eastern Slavs - the ancestors of Belarusian and Ukrainians - became the ethnic core of the Grand Duchy of Lithuania. ${ }^{203}$ Thus, Belarusian textbooks recognize connections to the Old-Russian nation, at the same time emphasizing Belarus's different path that it took in the Grand Duchy of Lithuania where the

\footnotetext{
${ }^{199}$ Ibid, 80.

${ }^{200}$ Ibid.

201 История Беларуси вторая половина XIII - первая половина XVI в. Учебное пособие для 7 класса общеобразовательных учреждений с русским языком обучения под редакцией Ю.Н. Бохана. (Минск: «Народная асвета», 2009), 122. The textbook claims that Romani people who lived in the Grand Duchy of Lithuania spoke either their own language or Belarusian. It is interesting because not the old-Belarusian mentioned as in some places, but Belarusian. 202 Ibid, 5.

${ }^{203}$ История Средних Веков XIV - XV вв. Учебное пособие для 7 класса под редакцией В.А. Федосика. (Минск: «Народная асвета», 2009), 126. Available: http://slovo.ws/urok/historymid/07/001/001.html
} 
Belarusian nation had been formed. The period of the Grand Duchy of Lithuania appears as the time when the Old-Russian Belarusian nation emerges as distinct from the Ukrainian and Russian nations.

The creation of the Grand Duchy of Lithuania marked the development of the main characteristics of Belarusian culture and its character, such as multi-confessionalism, religious and national tolerance, respect for various customs and cultures, the traditions of neighbors and openness. ${ }^{204}$ Thus, Belarusian textbooks from 2009/2010 precisely reflect the concepts and standards developed by the Ministry of Education of the Republic of Belarus where a strong emphasis is put on Belarusian tolerance, respect for other cultures and nations. Textbooks propagate a narrative of historical continuity with the national values and virtues of the Belarusian nation that are outlined in Belarusian official documents.

A certain level of continuity with the present appears in the textbook when the authors claim that "[Belarusian people] gathered strength in order to survive and appear in front of the world with its own history - heroic and sometimes dramatic." ${ }^{, 05}$ It certainly empowers the modern Belarusian nation as a nation with a distinct historical past where tragedies and hardships tempered its people. Once again, the Belarusian nation's development did not divert from the other East Slavs. During the Slavic colonization of the Belarusian lands, for example, Belarusian cities were built that led to the emergence of such historically important centers as Navahrudak, Grodno, and Volkovisskoe, which played an important role in the development of the Grand Duchy of Lithuania. ${ }^{206}$

Later, in the fourteenth century the narrative claims that Eastern Slavic lands were united under the rule of Grand Duke Gediminas (1315/16-1345). It is also said that the population of Belarusian lands retained their former way of living, language and culture after the Grand Duchy of Lithuania had been

\footnotetext{
204 История Беларуси вторая половина XIII - первая половина XVI в. Учебное пособие для 7 класса общеобразовательных учреждений с русским языком обучения под редакцией Ю.Н. Бохана. (Минск: «Народная асвета», 2009), 5.

${ }^{205}$ Ibid.

${ }^{206}$ Ibid, 10.
} 
created and therefore, it had not been "colonized" by the Grand Duchy of Lithuania. Furthermore, the highest authorities of the Grand Duchy of Lithuania did not intervene into the domestic affairs of Eastern Slavs. ${ }^{207}$ Such an interpretation is meant to show the relative autonomy of Eastern Slavs within the Grand Duchy of Lithuania by emphasizing the idea that Belarusians were independent from Lithuanians and the Grand Duchy of Lithuania in general. Such an idea is also stressed by claims that the Belarusian language became an official language of the Grand Duchy of Lithuania with a high rate of distribution and high percentage of population who considered themselves "Russian" - the description of Belarusians used in the medieval period. ${ }^{208}$ In addition, under the influence of the Belarusian people some parts of the Grand Duchy of Lithuania accepted Orthodoxy; among them were the Grand Duke Gediminas and his children.

Therefore, it seems that Belarusian history textbooks emphasize the "Belarusianness" of the Grand Duchy of Lithuania but at the same time the official national narrative tends to distance itself from the importance of the Grand Duchy in Belarus's modern identity. Thus, a contradiction is visible between the narrative presented in history textbooks and the official national narrative promoted by the government in Belarus's public sphere. On one hand, it seems logical for the nation-building process to emphasize the deep historical roots of Belarus and the "Belarusianness" of the Grand Duchy overall, however, it seems counterintuitive that the process of stressing Belarus's medieval past is not continued in Belarusian public sphere and by the government itself.

There is a strong emphasis within the narrative of Belarusian history textbooks on relative Belarusian self-sufficiency in the medieval period together with the idea that the Belarusian people contributed the most to the development of the Grand Duchy of Lithuania overall. Such emphasis on Belarusianness, however, is mixed with idea that the "Russian" people also populated the Grand Duchy

\footnotetext{
${ }^{207}$ Ibid, 18.

${ }^{208}$ Ibid, 19.
} 
of Lithuania. The question remains why the textbooks continue mentioning the Russian nation within the context of the Grand Duchy of Lithuania if they claim that "Russian" was a name for "Belarusian" at that time. It gets even more complicated when the textbooks claim that the maintenance of "Russian" lands within the Grand Duchy of Lithuania was dependent on satisfaction of the interests of Belarusian and Ukrainian lords. ${ }^{209}$ Thus, it seems that there is a constant mixture between the Russian and Belarusians in explaining their role within the Grand Duchy of Lithuania and its development. This device is used, however, to emphasize Belarusian historical ties to Eastern Slavic tribes and thus their connection to the modern Russian and Ukrainian nations.

In the textbooks, the Baltic tribes are mentioned as neighbors of Eastern Slavs with a long history of cohabitation. The Grand Duchy of Lithuania is mentioned as a common state of the Baltic and the Eastern Slavic tribes, and their interrelations are also portrayed in the textbooks. After outlining the official Belarusian national narrative as it appears in Belarusian history textbooks, it is worth focusing on the representation of Lithuanians in the same textbooks since it is the main Baltic nation whose ancestors shared the Grand Duchy of Lithuania.

\section{Representation of Lithuania within the Grand Duchy of Lithuania in Belarusian History Textbooks}

This textbook analysis is more like a caesura of Lithuanian representation in Belarusian textbooks at a particular time rather than an attempt to provide a larger examination of Belarusian treatment of Lithuania in its textbooks. As evident in the existing research, Belarusian narratives in history textbooks are subject to change based on particular regimes or nation-building policies of the state. Thus, the

${ }^{209}$ Ibid, 80 . 
following research is an attempt to see the Belarusian national narrative within the context of 2002-2009 period defined by Tatyana Ostrovskaya in her research.

The sixth-grade history textbook provides a clear narrative with regard to representation of Lithuanians during the origins of the Grand Duchy of Lithuania. Looking at the linguistic connotation of sentences used to address Lithuanians, however, it is possible to claim that Lithuanians are treated as less developed tribes. For example, the text reports that agriculture and the political level of development of Belarusian lands was higher than in Lithuanian lands. It also says that Baltic tribes until the thirteenth century had neither cities nor writing, but they experienced separation between the nobility and common people, i.e. feudalism. ${ }^{210}$ Furthermore, the narrative of the creation of Grand Duchy of Lithuania is the one of gradual and peaceful unification rather than a narrative of conquest by Lithuanian dukes. $^{211}$

Overall the text suggests a lack of written documentation about the Belarusian neighbors to the northwest. Although the textbook acknowledges that Lithuania was first mentioned in 1009, it claims that it is not precisely clear what this name meant and where it came from. ${ }^{212}$ In the thirteenth century, however, a group of Baltic tribes neighboring Belarusian lands had already united and started to call themselves "Aukštaiti," while a second similar union started to be called "Žemaiti." Moreover, they had come very close to establishing their own state. ${ }^{213}$ This distinction in Belarusian history textbooks is crucial in understanding how the Belarusian narrative is describing present-day Lithuania - as descendants from Aukštaitija rather than from the Grand Duchy of Lithuania.

\footnotetext{
${ }^{210}$ История Беларуси с древнейших времён до середины ХІІІ в. Учебное пособие для 6 класса под редакцией Г.В. Штыхова и Ю.Н. Бохана. (Минск «Издательский центр БГУ» 2009), $95 . \quad$ Available at: http://slovo.ws/urok/historyofbelarus/06/001/001.html

${ }^{211}$ Ibid, 87.

${ }^{212}$ Ibid, 96 .

${ }^{213} \mathrm{Ibid}, 95$.
} 
The seventh-grade history textbook, focusing on the first half of thirteenth century until the first half of sixteenth century, devotes greater attention to Lithuania as a separate nation because it is precisely the time when the Grand Duchy of Lithuania had been formed. For that matter, the textbook claims that the political union of two nationalities - Lithuanian and Belarusian - formed the Grand Duchy of Lithuania. ${ }^{214}$ Furthermore, a very close nexus existed between the two nations that allowed them to develop a common state with the political center located in the city of Navahrudak and neighboring Lithuanian lands. ${ }^{215}$

Despite the fact that the existence of a separate Lithuanian nation is recognized, its importance in the creation of the Grand Duchy of Lithuania is not clearly defined in the textbooks. For example, due to the later acquisition of Ukrainian lands the Duchy was named "the Grand Duchy of Lithuania and Russia." But later, with the acquisition of Žemaitija, it started to be called "the Grand Duchy of Lithuania, Russia and Žemaitija." ${ }^{216}$ A narrative that Lithuanians are descendants from Aukštaitija is supported also in this textbook claiming that Lithuania was a separate region within Aukštaitija and a center of unification of the Baltic tribes. Later, all parts of Aukštaitija and even some parts of Žemaitija started to be called Lithuania. ${ }^{217}$ Furthermore, due to the gradual colonization of the region by the Slavs, not only the Baltic people populated Aukštaitija. Eventually it led to the dependency of Lithuanian lands on Russian monarchs who would collect taxes and exercise their power over Lithuanian lands. ${ }^{218}$

The narrative of underdevelopment among the Baltic tribes continues through descriptions of the Slavic lands as more developed since they had bigger cities, and more advanced crafts, traditions and

\footnotetext{
214 История Беларуси вторая половина ХIII - первая половина XVI в. Учебное пособие для 7 класса общеобразовательных учреждений с русским языком обучения под редакцией Ю.Н. Бохана. (Минск «Народная асвета» 2009), 5 .

${ }^{215}$ Ibid, 120.

${ }^{216}$ Ibid, 19.

${ }^{217}$ Ibid, 9 .

${ }^{218}$ Ibid, 11 .
} 
state organization. ${ }^{219}$ Moreover, the Baltic tribes entered the period of organizing their statehood only in the twelfth and thirteenth centuries, which explained their increasing militancy. A more critical explanation of Lithuanian society is also given in the claim that by the thirteenth century an undeveloped form of slavery existed there due to division on nobles and common people. ${ }^{220}$ This did not prevent the Grand Duchy, however, from becoming an independent power within the region that would challenge Muscovites, Poles and German invaders.

The establishment of the Grand Duchy of Lithuania is directly connected with the expansion Mindaugas's lands to Belarusian lands, including the important city of Navahrudak. King Mindaugas is an important character in the history of Grand Duchy of Lithuania with whom the beginnings of the Grand Duchy of Lithuania are connected. ${ }^{221}$ According to the textbook, Mindaugas accepted the Catholic faith in order to become the king of the Grand Duchy of Lithuania in 1253. In 1261, however, he gave up the Catholic faith and turned back to paganism which is also proven by claims that Mindaugas secretly burned the bodies of his enemies to please the gods, etc. ${ }^{222}$ It is possible that by projecting Mundaugas's faith as not entirely Catholic, Belarusian textbooks are leaving space to interpret him as not precisely a Catholic or pagan king but rather as the king who might have also adopted the Orthodox faith instead of Catholicism.

So far, the representation of Lithuanians is mixed - neutral or rather negative. The Belarusian narrative in the seventh-grade textbook portrays Lithuanians as capable of uniting the lands and being militarily superior to the extent that some Belarusian lands would even ask Lithuanian rulers to be accepted under their protection due to the level of military organization the Lithuanians had. ${ }^{223}$ When talking about the Grand Duchy of Lithuania as a political entity, however, the narrative seems to

\footnotetext{
${ }^{219}$ Ibid, 8 .

${ }^{220} \mathrm{Ibid}, 12$.

${ }^{221}$ Ibid, 13.

${ }^{222}$ Ibid, 16.

${ }^{223}$ Ibid.
} 
diminish the "Lithuanianness" of the Grand Duchy by showing that the Slavic language and culture had greater importance than that of the Baltic tribes. For example, the text claimed that the Belarusian language had high rates of distribution and became the official language of the state; therefore, almost $3 / 4$ of the population called themselves "Russians" ("Русьскими"). Such claims support the official narrative that Belarusians of that time were called Russians. ${ }^{224}$

The textbook's narrative does not only diminish the Lithuanians importance in that period but also seeks to enhance and empower the Belarusianness and Russianness of the Duchy, giving examples that King Gediminas would call himself "the king of Lithuania and Rus"” or "the king of Lithuanians and many Russians." 225 Or, that in order to keep the "Russian" lands within the Grand Duchy of Lithuania, it was necessary to meet the interests of Belarusian and Ukrainian lords. ${ }^{226}$ Thus, Belarusian history textbooks refer to the inhabitants of the Grand Duchy of Lithuania as being mainly Russian with certain Belarusian aspects such as culture and language. Belarusian history textbooks, therefore, claim that Belarusians in the medieval period were called Russians due to close intermingling of Eastern Slavic tribes.

The aforementioned interpretations show interdependency among the Balts and the Slavs of that period by depicting the Grand Duchy of Lithuania as a product of both Baltic and Slavic tribes. The presence of "Russian" is not always understandable and means that the textbook's narrative is deliberately using the interpretations of Russianness to claim that the Grand Duchy of Lithuania was a multifaceted creation where Eastern Slavs were Belarusians but the Belarusians, however, were sometimes called "Russians." At the same time, there are intentions to diminish the role of the Lithuanian nation in the Grand Duchy of Lithuania by claiming that Lithuania and the Grand Duchy of Lithuania were two separate entities. More precisely, Lithuanian and Belarusian lands united in order to

\footnotetext{
${ }^{224}$ Ibid, 19.

${ }^{225}$ Ibid.

${ }^{226}$ Ibid, 80 .
} 
establish a common state, which was not a product of only one side's intentions. Such an interpretation is portrayed in an illustration from the textbook where separate names are given for the Lithuanian lands, the Grand Duchy of Lithuania lands and the Belarusian lands (see below).

Illustration Nr. 4.1

\section{The Grand Duchy of Lithuania in second half of XII - first half of XIV centuries}

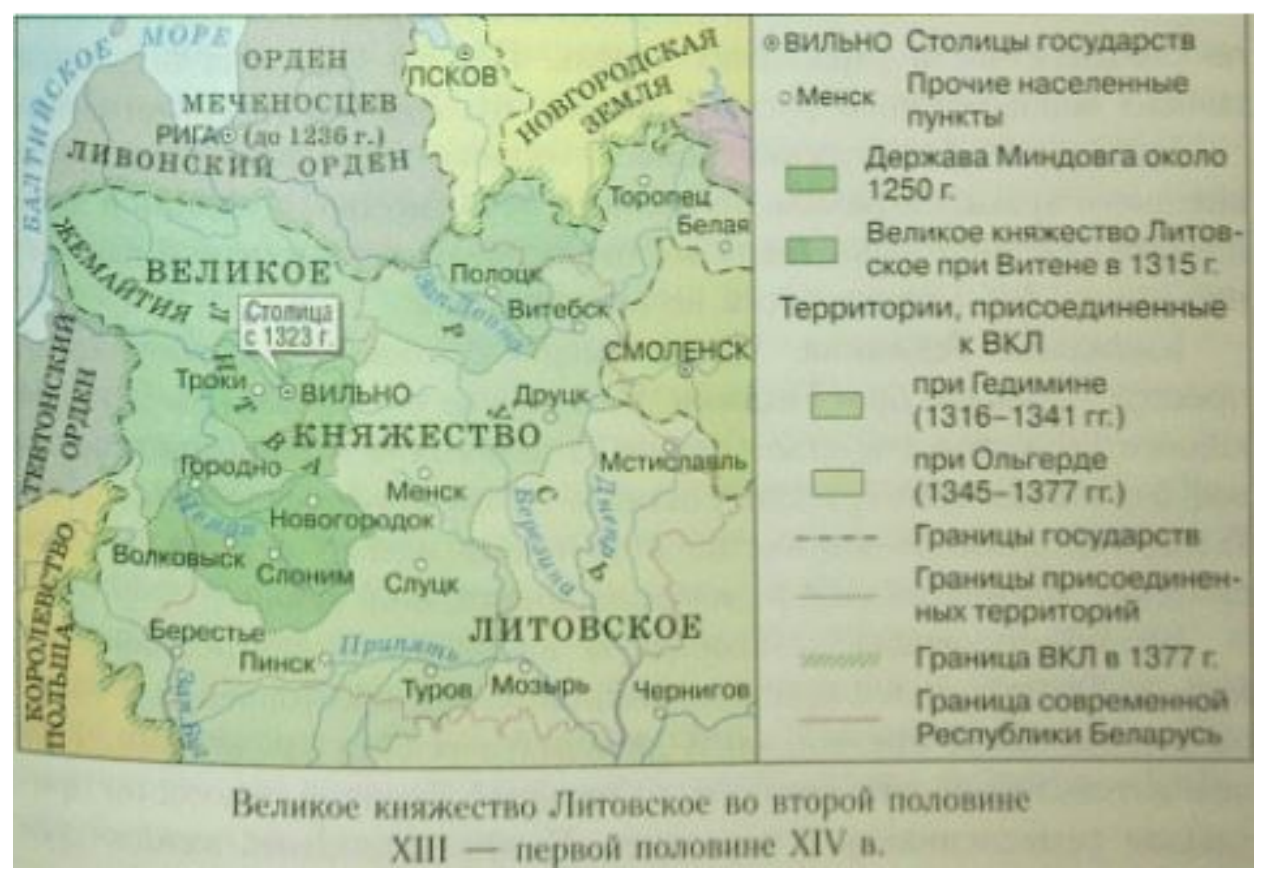

Source: История Беларуси вторая половина XIII - первая половина XVI в. Учебное пособие для 7 класса общеобразовательных учреждений с русским языком обучения под редакцией Ю.Н. Бохана. (Минск «Народная асвета» 2009), 17.

As seen on the map, a separate name is given for Lithuanians lands (Литва), a separate name for the Grand Duchy of Lithuania lands (Великое Княжество Литовское) and a separate name for the Belarusian lands (Русь). Such a representation suggests that the Grand Duchy as something alienated from Lithuanian and Belarusian histories. It seems that Belarusian interpretation asserts the Grand Duchy as something independent from both histories without emphasizing any nation's importance. For example, neither of the Grand Dukes of the Grand Duchy of Lithuania (Grand Dukes Gediminas and Vytautas and King Mindaugas) is given any nationality in Belarusian textbooks; they are seen as rulers 
of the Grand Duchy rather than representatives of Baltic or East-Slavic nationalities. Moreover, the inhabitants of the Grand Duchy were called "Litvins" to emphasize their belonging to a particular political entity of the medieval period rather than a separate twenty-first century state. ${ }^{227}$ Maybe exactly for that reason Belarusian history textbooks do not emphasize the Grunwald battle of 1410, simply saying that there was a war with the Teutonic Order from 1409 until $1411 .^{228}$ Such silencing of a particular event that has a glorious meaning in Lithuania might be seen as an attempt to refrain from empowering Lithuanian national narrative.

This research has shown that there is a lack of focused orientation on the image of Lithuanian nation and its overall representation in Belarusian history textbooks. Lithuanians are mostly mentioned in connection with Belarusians as co-creators of the Grand Duchy of Lithuania. When the Lithuanian nation is mentioned, however, there is a deliberate tendency to represent it as originating from less developed tribes in comparison to Eastern Slavic tribes. Thus, even though Lithuanians are represented, it is done to show their underdevelopment in social and cultural matters rather than their historical importance. Their militancy, however, is emphasized in positive terms to portray it as a reason for the Belarusian lands to seek protection from Lithuanian forces against external threats such as that posed by the German crusaders.

The fact that Belarusian history textbooks tend to diminish Lithuanian representation and importance seems logical due to the significance of education in the nation-building process that was outlined in the theoretical framework for this research. Despite different interpretations of Lithuanian input into the creation and maintenance of the Grand Duchy of Lithuania, the Belarusian narrative tends

\footnotetext{
${ }^{227}$ История Беларуси Вторая половина XVI - конеи XVIII в. Учебное пособие для 8 класса общеобразовательных учреждений с русским языком обучения (Минск «Издательский центр БГУ» 2010), 15.

228 История Беларуси вторая половина XIII - первая половина XVI в. Учебное пособие для 7 класса общеобразовательных учреждений с русским языком обучения под редакцией Ю.Н. Бохана. (Минск «Народная асвета» 2009), 58 and История Средних Веков XIV - XV вв. Учебное пособие для 7 класса под редакцией В.А. Федосика. (Минск «Народная асвета» 2009), 87. Available: http://slovo.ws/urok/historymid/07/001/001.html
} 
to emphasize the Belarusianness of the Grand Duchy of Lithuania where possible, as outlined in the previous chapter, rather than to purposefully "rewrite" Lithuanian history of that period. In this regard, combining Belarusian representation and Lithuanian representation in Belarusian history textbooks, it is possible to draw certain general conclusions about patterns of interpretations used in the Belarusian history textbooks under analysis. 


\section{CONCLUSION}

Even though having only one major research question, this Master's thesis has provided answers to several broader questions regarding Belarus's post-1991 nation-building process. First of all, by its very existence this research contested the point that Belarus is a "denationalized" nation that failed to produce a consolidated nation after the fall of the Soviet Union. The research indicated that the process of consolidation of the Belarusian nation has developed more recently due to the complicated domestic configurations, which existed before 2002 and partially, continue to exist now. Therefore, Belarus should not be considered the "denationalized" state, but a state with rather complicated national identity that is divided between the expressions of the official and the alternative national narratives in Belarus's public sphere. In recent years, however, with the strong influence of the official narrative and government's nation-building policies, Belarusian identity has consolidated and is able to represent a nation.

Therefore, previous studies on various expressions of Belarusian nationalism should be reconceptualized due to the changing policies of the Belarus's nation-building process. More precisely, the official Belarusian national discourse no longer resembles the pro-Russian version but rather focuses on re-consideration of historical "Belarusianness" by placing emphasis on historical aspects and qualities of the Belarusian people rather than on the importance of historical political formations. Official discourse wants to promote the concept of sovereign and modern Belarusian nation that is the product of the complicated nation-building process, which, in turn, started with the identity-formation in medieval times and continued with the political development of the state during the Soviet period. Nowadays it is in the process of merging the pre-Russian and the medieval characteristics with the Soviet-era state formation of Belarus. 
Also, this thesis signifies that the existing research on Belarusian history textbooks does not clearly interpret the idea of Belarusian nationhood, claiming that history textbooks after 2002 simply started looking for Belarusian antiquity. My research, on the other hand, shows that Belarusian textbooks started combining the alternative national narrative of the distinct pre-Soviet roots of Belarusian nation together with the official pro-Russian national narrative by acknowledging that the Belarusian nation's roots belong to Eastern Slavic people who are closely related to the other Slavic nations of Russia and Ukraine.

In general, the overview of the post-1991 nation-building process has revealed the interconnection between the change of the domestic nation-building narratives and the change in foreign policy choices in terms of Belarus's self-identification within the region. Therefore, the period from 1991 until 1994 marked Belarus's orientation towards the West rather than Russia due to the strong ethnocentric nationalism expressed by the Belarusian Popular Front in early 1990s. Negation of the Soviet past shaped Belarus's orientation away from Russia.

After 1994, however, the pro-Western orientation was substituted with an increasingly close political and economic integration with Russia. In a series of referenda, Belarus's pre-Soviet symbols where changed to the flag and the coat of arms that emphasized its direct relation to Soviet values. In the period from 1994 until 2002 Belarus was extremely interested in strengthening its ties with Russia, disregarding the pre-1994 connections with the West. The Belarusian rhetoric towards the West, however, has changed remarkably since 2002 and allowed Belarus to become a part of the European Neighborhood Policy in 2004. Later in 2009 Belarus became a part of the Eastern Partnership of the European Union. Even though there is a lack of bilateral cooperation between the two actors, which presently is also marked by the European Union sanctions towards Belarus, the presence of the official 
and the alternative national narratives has allowed Belarus to reconsider its position and partners within the region.

Nowadays, with the stress on Belarus's independence and sovereignty in its domestic national rhetoric, Belarus conducts a rather independent and pragmatic foreign policy in terms of its alignment with the West of with the Russian Federation. The Belarus-EU relations are developing slowly and largely depend on Belarus's willing to cooperate further, primarily in non-economic questions. The Belarus-Russia relations, on the other hand, are conducted with the pragmatic idea of Belarus's benefits. Despite the fact that Belarus continues to connect itself with Russia historically, the present political and economic connection develops via the multilateral network rather than bilateral integration. This attitude is revealed in the process of creation of the Eurasian Economic Union, in which Lukashenka stated that Belarus needs clear economic benefits from the Union rather than simple symbolic value of its premature creation in 2015.

The aforementioned connections between the domestic nation-building narratives and Belarus's self-identification within the region have revealed the far-reaching implications of the nation-building process in Belarus. It is enlightening to see how particular national narratives relate not only to the domestic configurations within the state, but also directly influence the country's foreign policy choices.

In terms of the research aim of understanding Belarus's nation-building process, this Master's thesis has fulfilled it. This research has revealed the existence of two national narratives in the Belarus's public sphere that appeal to different values and different periods of the Belarus's history. This research has defined the official and the alternative national narratives as the most persistent narratives in Belarus's public sphere. The official national narrative should be seen as the government's product because it is revealed in the official campaigns, rhetoric as well as in the system of education. The alternative national narrative, on the other hand, represents various ideas and narratives, which do not 
comply with the officially promoted history, memory and national values of the modern state. Therefore, in line with the existence of the two narratives, the Belarus's history textbooks possess the values and ideas of the official national narrative, even if it contains features of the alternative narrative.

The main question of this research was centered on the problem of the representation of Lithuania and Lithuanians in Belarus's history textbooks. In line with the research question, the first hypothesis of the Master's thesis was defined as follows: the Belarusian national narrative in history textbooks does not challenge the Lithuanian national narrative, but seeks to highlight and empower the "Belarusianness" of their shared past for the nation-building purposes. Based on the research conducted for this thesis, it is possible to conclude that this hypothesis appears to be partially falls because with the process of empowering the "Belarusianness" and the emphasis on the supremacy of the Belarusian lands in comparison to the Lithuanian lands, the history textbooks do challenge the Lithuanian national narrative by diminishing their historical significance in the period that is considered "glorious" in Lithuania. The history textbooks' narrative, however, does not seek to "rewrite" the Lithuanian past because it should be seen as an outcome of the complicated nation-building process, in which there is no unanimity on the value of Belarus's medieval past.

Belarusian history textbooks tend to promote Belarusian national identity together with tolerance towards other regional identities and cultures. Therefore, it is concluded that the history of the Grand Duchy of Lithuania is presented as a complex process of Belarusian and Lithuanian cooperation that in the middle of thirteenth century produced an independent political entity. The image of the Lithuanian nation, however, is presented as being underdeveloped in comparison to their East-Slavic neighbors or neutral when it comes to general perception of Baltic tribes and their role in the development of a common state. 
This study also concludes that the Belarusian history textbooks seek to portray the Grand Duchy of Lithuania as an independent medieval political entity that is detached from the modern political entities of Belarus and Lithuania. Despite the role the Grand Duchy of Lithuania played in developing a Belarusian nation, nothing is clearly stated about the importance of the Grand Duchy of Lithuania in the establishment of the Lithuanian nation. In support of this idea, the history textbooks claim that the "Litvins" - a sort of a separate nation of the medieval state - populated the Grand Duchy of Lithuania and neither the Lithuanians nor the Belarusians. The narrative of "Litvins," however, is not the main concern of the textbooks; it is more promoted by individual scholars. ${ }^{229}$ It is said that Litvins were the inhabitants of the Great Duchy of Lithuania, but the textbook also say that the Baltic tribes Lithuanians, the Eastern Slavic people - Belarusians, Russians, and Ukrainians lived in the Grand Duchy and comprised its core population. It means that the Lithuanians also are considered to be Litvins, however, such argument is not clearly emphasized due to the peculiarities of the official national narrative of Belarus. In general, history textbooks have a tendency to silence and empower certain interpretations and events of the past. Therefore, it might be concluded that the Litvin narrative is not emphasized in the textbooks because it stands as clearly alternative Nativist narrative to the proRussian official national narrative. With no direct intentions to challenge the Lithuanian past, Belarusian textbooks empower Belarusian narrative for the purposes of modern nation-building, as well as for the purposes of finding deep historical roots of the Belarusian nation which is relevant for the 2002-2009 period outlined by Tatyana Ostrovskaya in her research.

This Master's thesis, however, has revealed an interesting connection between the official national narrative that is promoted in Belarus's public sphere and the narrative with regard to the Grand Duchy of Lithuania in Belarus's history textbooks. It has been discussed in the thesis that the official

\footnotetext{
229 Jan Zaprudnik, Belarus: At a Crossroads of History (Westview Press, 1993), 4. Or Yaroslav Shimov, "Belorussia: Vostochnoevropeiskii paradoks" Neprikosnovennyi zapas, $3, \quad 47 \quad$ (2006), available: http://magazines.russ.ru/nz/2006/47/sh11.html
} 
national narrative tends to distance itself from the Belarus's medieval past claiming that it does not fully represent the values of the modern Belarusian state. The narrative in the history textbooks, however, contradicts the official narrative in terms of its emphasis on the "Belarusianness" of the Grand Duchy of Lithuania. The history textbooks emphasize the supremacy of the Belarusian lands over the Baltic lands and claim that the Grand Duchy of Lithuania was subjected to the strong influence of the Belarusian people and the Belarusian language. Therefore, future researchers might ask the question why the official national narrative is distancing itself from the Grand Duchy of Lithuania and its historical influence on the modern Belarus's state, but the history textbooks, in turn, emphasize the presence and influence of Belarus and its culture on the medieval political entity. Thus, it is possible to conclude that there is a lack of harmonization between the official national narrative and its expressions in the history textbooks.

The existence of this contradiction between the official national narrative and the history textbooks' narrative is very interesting because the narrative of Belarusian history textbooks itself is extremely contested within Belarus and among the Belarusian scholars. There is an ongoing debate about the problem of "rewriting" of Belarusian history with regard to the medieval period and twentieth century history. The problem with the medieval period is that Belarusian textbooks are accused of silencing Belarusian roots of the Grand Duchy of Lithuania, i.e. not highlighting them enough to emphasize the Belarusian deeds. On the other hand, there is a concern that the twentieth-century period is being interpreted to whitewash the Soviet system, when the official narrative states that precisely this period should be considered the primary nation-building period of Belarusians.

Nevertheless, the Belarusian national narrative in history textbooks should be seen as a product of diverse Belarusian nation-building processes that have been developing since 1991. The national narratives had been changed several times from pro-European in early 1990s to pro-Soviet in mid-1990s 
and later to more moderate hybrid "Creole" narrative after 2002 that incorporates some aspects of the two previous models. Under the domestic process of nation-building, the official national narrative incorporates certain aspects of the alternative national narrative that makes it reconsider some aspects of representation of Belarusian past in the history textbooks. In this regard, the Belarusian official national narrative in history textbooks should be treated as an attempt to define the Belarusian national identity rather than to "rewrite" the Lithuanian past. Such attempts, however, definitely challenge the Lithuanian national narrative because they differ in substantial matters about central aspects of Lithuanian past such as the place of coronation of King Mindaugas.

This research has analyzed particular examples from the Belarusian textbooks of the conflicting narratives of the shared Lithuanian and the Belarusian past in order to show the changing pattern of the Belarusian national narrative, which is incorporating some reasoning of the alternative narrative which exists parallel to the official narrative.

Therefore, it is also possible to evaluate the second hypothesis for this research, which was formulated as follows: the more the official Belarusian narrative tries to establish a Belarusian national idea, the more it resembles the alternative narrative of Belarusian opposition. As it was shown throughout this research, the post-2002 official national narrative has recognized the influence of Belarus's medieval past on modern Belarusian identity. It should be concluded that due to the complexity of Belarus's history and post-1991 nation-building process, Belarus's government in the 2000s could no longer disregard the influence of its medieval past because it was constantly revived by reenactment groups, musical bands, public initiatives on erection of monuments etc.

This particular research indicated that the Belarusian textbooks started combining the two narratives of distinct historical roots of the Belarusian nation together with the acknowledgement of the 
fact that the Belarusian nation's roots belong to the Eastern Slavic people who are closely related to other Slavic nations of Russia and Ukraine. The second hypothesis is therefore supported by the research

The textbooks promote the idea of the Belarusian nation as an outgrowth from the Old-Russian nation that united Belarusians, Russians and Ukrainians in one region. The textbooks do not consider it important to mention the nationality of such important historical figures as the King Mindaugas, and Great Dukes Gediminas and Vytautas. This means that the textbooks see the Grand Duchy of Lithuania as an independent period within the history of Belarus that was ruled by relatively independent historical nations who also appear to be ancestors of modern regional nations, but not more than that. Moreover, history textbooks reflect the essence of Belarusian official documents of the Ministry of Education of the Republic of Belarus where the Grand Duchy of Lithuania is treated as a separate entity that is not a direct ancestor of the modern Belarusian state. The official Belarusian national narrative does not stress the importance of the Grand Duchy of Lithuania in its political terms, but rather considers it as a time when Belarusian national consciousness developed in distinctive ways from the Old-Russian nation.

One might suggest that it is an intention of the Belarusian state to rewrite the Lithuanian past in order to emphasize its national heritage and deep historical roots. This assumption, however, is rather simplistic since it fails to comprehend the complexity of Belarusian domestic nation-building process. Professor V. Rakutis from Lithuania, however, claimed that Belarusian textbooks are rewriting Lithuanian past and might even contest the present Lithuanian heritage. After this study's analysis of Belarusian nation-building and the development of the Belarusian national narrative, it appears that Belarus has no intentions to rewrite the Lithuanian past since the official national narrative presented in textbooks is a direct reflection of complicated process of the making of Belarusian identity. Before 2002 the Belarusian official national narrative did not contest the Lithuanian past on the same level it contests today because the broader recognition of the pre-Soviet and pre-imperial past came only after 2002 . 
Therefore, the modern process of nation-building is a reflection of complicated domestic process of understanding of Belarusian communality that nowadays includes recognizing aspects of both pro-soviet and pro-European narratives.

Finally, this Master's thesis concludes that the official Belarusian national narrative in Belarusian history textbooks does not consciously "rewrite" the Lithuanian past, however, it definitely challenges the Lithuanian interpretation of the shared medieval past of Belarus and Lithuania. More comprehensive research involving a broader perspective and the larger choice of history textbooks, however, is needed to fully master the exact impact the official Belarusian national narrative has had on the Lithuanian national narrative. In doing so, an analysis of Lithuanian history textbooks is vital. 


\section{BIBLIOGRAPHY}

\section{Primary sources:}

Alyaksandr Lukashenka's speech during the special Presidential Award "For Spiritual Revival. Minsk, January 9, 2014. President of the Republic of Belarus. www.president.gov.by. Available: http://president.gov.by/ru/news_ru/view/aleksandr-lukashenko-prinjal-uchastie-v-tseremoniivruchenija-premii-za-duxovnoe-vozrozhdenie-i-spetspremij-7789/

From the record of Alyaksandr Lukashenka's speech in front of the student youth of Brest. September 23, 2004. President of the Republic of Belarus www.president.gov.by. Available: http://www.president.gov.by/ru/news_ru/view/stenogramma-vystuplenija-pered-studencheskojmolodezhjju-brestchiny-5916/

История Беларуси с древнейших времён до середины XIII в. Учебное пособие для 6 класса под редакцией Г.В. Штыхова и Ю.Н. Бохана. Минск: «Издательский центр БГУ», 2009. Available: http://slovo.ws/urok/historyofbelarus/06/001/001.html

История Беларуси вторая половина XIII - первая половина XVI в. Учебное пособие для 7 класса общеобразовательных учреждений с русским языком обучения под редакцией Ю.Н. Бохана. Минск: «Народная асвета», 2009.

История Средних Веков XIV - XV вв. Учебное пособие для 7 класса под редакцией В.А. Федосика. Минск: «Народная асвета», 2009. Available: http://slovo.ws/urok/historymid/07/001/001.html

История Беларуси Вторая половина XVI - конец XVIII в. Учебное пособие для 8 класса общеобразовательных учреждений с русским языком обучения. Минск «Издательский центр БГУ» 2010.

Министерство Образования Республики Беларусь. “Образовательный стандарт учебного предмета “Всемирная История. История Беларуси” (5-11 классы).” No. 32, Мау 29, 2009.

Министерство Образования Республики Беларусь. “Концепция учебных предметов - “Всемирная история. История Беларуси.” №. 675, Мау 29, 2009.

Национальная комиссия по устойчивому развитию Республики Беларусь. Национальная стратегия устойчивого социально-экономического развития Республики Беларусь на период до 2020 г. Минск: Юкипак, 2004.

Национальный правовой интернет-портал Республики Беларусь www.pravo.by. Постановление Совета Министров Республики Беларусь 4 ноября 2006 г. № 1475. Available: http://www.pravo.by/main.aspx?guid $=3871 \&$ p0 $=\mathrm{C} 20601475 \& \mathrm{p} 2=\{\mathrm{NRPA}\}$ 


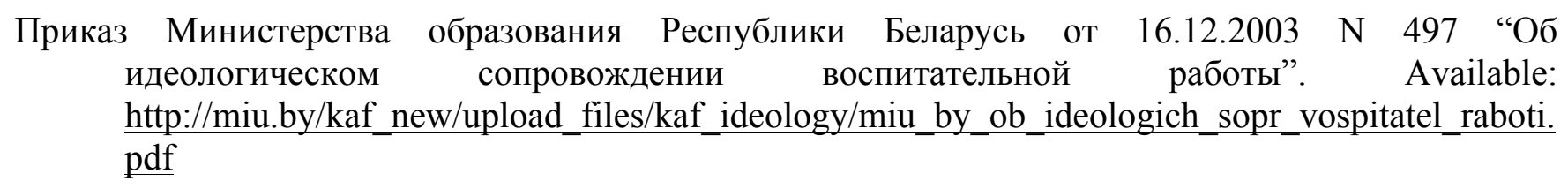

\section{Secondary sources:}

Anderson, Benedict. Imagined Communities: Reflections on the Origin and Spread of Nationalism. London: Verson, 1983.

Assmann, Aleida. "Transformations Between history and Memory." Social Research, Vol. 75. No. 1 Collective Memory and Collective Identity (Spring 2008).

Assmann, Aleida. "To Remember or to Forget: Which Way Out of a Shared History of Violence?" In Memory and Political Change. Palgrave Macmillan, 2012.

Hobsbawm, Eric. "Introduction: Inventing Traditions." In The Invention of Tradition, edited by Eric Hobsbawm and Terence Ranger. Cambridge: Cambridge University Press, 1992.

Bekus, Nelly. "European Belarus versus State Ideology: Construction of the Nation in the Belarusian Political Discourses." Polish Sociological Review, No. 163 (2008).

Bekus, Nelly. Struggle Over Identity. The Official and the Alternative "Belarusianness." Budapest: Central European University Press, 2010. Available: http://books.openedition.org/ceup/581

Buhra, Renee L., Shadurski, Victor and Hoffman, Steven. "Belarus: an emerging civic nation?" Nationalities Papers, Vol. 39, No. 3, (May 2011).

Brown, Anthony. "Language and Identity in Belarus." Language Policy (2005).

Coulter, Cathy and Smith, Mary Lee. "The Construction Zone: Literary Elements in Narrative Research.” Educational Researcher 38(8) (2009).

Collingwood, Robin. The Idea of History. Edited by Jan Van der Dussen. New York: Oxford University Press, 2005.

Collingwood, Roger. The Historical Imagination, An Inaugural Lecture delivered before the University of Oxford on 28 October 1935. Oxford: The Clarendon Press, 1935.

Crawford, Keith. "The Role and Purpose of Textbooks." International Journal of Historical Learning, Teaching and Research 3(2) (2003a).

Erickson, Frederick. "Qualitative Methods in Research on Teaching." In Handbook of Research on Teaching. Edited by Merlin Wittrock. New York: MacMillan, 1986.

Gellner, Ernest. Nations and Nationalism. Ithaca, London: Cornell University Press, 1983. 
Green, Anna and Troup, Kathleen. The Houses of History: A critical Reader in Twentieth-century History and Theory. Manchester: Manchester University Press, 1999.

Green, Andy. Education, Globalization and the Nation State. Palgrave Macmillan, 1997.

Green, Andy. "Education, Globalization and the Role of Comparative." London Review of Education, Vol. 1, No. 2, (July 2003).

Green, Andy. Education and State Formation: Europe, East Asia and the USA. $2^{\text {nd }}$ Edition. Palgrave Macmillan, 2013.

Green, Abigail. Fatherlands: State-Building and Nationhood in Nineteenth Century Germany. Cambridge: Cambridge University Press, 2001.

Hobsbawm, Eric. "Introduction: Inventing Traditions." In Nationalism: Critical Concepts in Political Science Edited by John Hutchinson and Anthony D. Smith, Volume 1. London, New York: Routledge, 2000.

Hroch, Miroslav. Social Preconditions of National Revival: A comparative Analysis of the Social Composition of Patriotic Groups among the Smaller European Nations. Cambridge University Press, 1985.

Hughes-Warrington, Marine. "How Good an Historian Shall I Be?” R.G. Collingwood, the Historical Imagination and Education. British Idealist Studies. Series 2: Collingwood, Volume 2. Bedfordshire: Andrews UK, 2003.

Inssitt, John. "Reflections on the study of textbooks." History of Education, Vol. 33, No. 6 (November, 2004).

Ioffe, Grigory. "Understanding Belarus: Belarusian Identity." Europe-Asia Studies, Vol. 55, No. 8 (December, 2003).

Ioffe, Grigory. "Culture Wars, Soul-Searching, and Belarusian identity." East European Politics and Societies, Vol. 21, No. 2 (2007).

Kasperski, Tatiana. "The Chernobyl Nuclear Accident and Identity Strategies in Belarus." In History, Memory and Politics in Central and Eastern Europe: Memory Games. Edited by Georges Mink and Laure Neumayer. New York: Palgrave Macmillan, 2013.

Kuzio, Taras. "History, Memory and National Building in the Post-Soviet Colonial Space." Nationalities Papers, Vol. 30, No. 2 (2002).

Leshchenko, Natalia. "A fine instrument: two nation-building strategies in post-Soviet Belarus." Nations and Nationalism 10 (3). (2004). 
Mamul, Natalia. "Narrative Templates of Post-Soviet Identity in Belarus." Polish Sociological Review, No. 166 (2009).

Megill, Allan. Historical Knowledge, Historical Error: A Contemporary Guide to Practice. With contributions by Steven Shepard and Phillip Honenberg. London: The University of Chicago Press, 2007.

Mironowicz, Eugeniusz and Slomczynska, Jerzyna, "The Attitudes of Belarusians and Poles towards the Independence of Their Countries." International Journal of Sociology, Vol. 31, No. 4, Belarus: Between the East and the West (II) (Winter 2001/2002).

Nicholis, Jason. "Methods in School Textbook Research." International Journal of Historical Learning, Teaching and Research 3(2) (2003a).

Pershai, Alexander. "Minor Nation: The Alternative Modes of Belarusian Nationalism." East European Politics and Societies Vol. 24, No. 3. (Summer 2010).

Renan, Ernest. "'From "What is a Nation?" In Collective Memory Reader, Edited by Jeffrey Olick, Vered Vinitzky-Seroussi and Daniel Levy. Oxford University Press, 2011.

Savchenko, Andrew. Belarus - A Perpetual Borderland. Leiden, Boston: Brill, 2009.

Sahm, Astrid. "Political Culture and National Symbols: Their Impact on the Belarusian NationalBuilding Process." Nationalities Papers, Vol. 27, No. 4, (1999).

Shimov, Yaroslav. "Belorussia: Vostochnoevropeiskii paradox." Neprikosnovennyi zapas. No. 3 (47) (2006). Available: http://magazines.russ.ru/nz/2006/47/sh11.html

Smith, Anthony D. National Identity. Reno: University of Nevada Press, 1991.

Smith, Anthony D. Nations and Nationalism in Global Era. Polity Press, 1995.

Smith, Anthony D. Nationalism and Modernism: a Critical Survey of Recent Theories of Nations and Nationalism. London, New York: Routledge, 1998.

Smith, Anthony D. Nationalism: Theory, Ideology, History. Polity, 2001.

Smith, Anthony D. "From the Ethnic Origins of Nations." In Collective Memory Reader, Edited by Jeffrey Olick, Vered Vinitzky-Seroussi and Daniel Levy. Oxford University Press, 2011.

Snyder, Timothy. Reconstruction of Nations: Poland, Ukraine, Lithuania, Belarus, 1569-1999. New Haven: Yale University Press, 2003.

Trouillot, Michel-Rolph. Silencing the Past: Power and the Production of History. Boston: Beacon Press, 1995. 
Vakar, Nicholas. Belorussia: The Making of A Nation. Cambridge: Harward University Press, 1956.

White, Hayden. “The Historical Text as Literary Artifact.” Tropics of Discourse (1978).

Wilson, Andrew. Belarus: the Last Dictatorship in Europe. New Haven, London: Yale University Press, 2011.

Zaprudnik, Jan. Belarus: At a Crossroads of History. Westview Press, 1993.

Zaprudnik, Jan. "Development of Belarusian National Identity and Its Influence on Belarus's Foreign Policy Orientation." In National Identity and Ethnicity in Russia and the New States of Eurasia. Edited by Roman Szporluk. New York: M.E. Sharpe, 1994.

Zerubavel, Yael. "The Historic, the Legendary, and the Incredible: Invented Tradition and Collective Memory in Israel." In Commemorations: the Politics of National Identity, edited by John Gillis. Princeton: Princeton University Press, 1994.

Zdanowicz, Francois. Myths of Nationhood and Support for State Sovereignty in Belarus. A dissertation submitted $\mathrm{n}$ partial satisfaction of the requirements for the degree Doctor of Philosophy in Political Science, University of California, UMI Number: 3559851 (March 2013).

Беларусь: ни Европа, ни Россия. Мнения белорусских элит. Под редакцией Валера Булгакова. Варшава: Издательство "ARCHE," 2006.

Мечковская, Нина. «Почему в постсоветской Беларуси всё меньше говорят на белорусском языке?» Неприкосновенный Запас № 6, 80 (2011).

Островская, Татьяна. Генеология Исторической Памяти Белорусов в Контексте Образовательных Практик. (Genealogy of Historical Memory of Belarusian in Context of Education Practices). Belarusian Institute for Strategic Studies, SA \#1/2010RU. October 20, 2010.

Чернявская, Юлия. Белорусы:: от "тутэйшых" к нащии. Минск: ФУАинформ, 2010.

\section{Online sources:}

Charter'97, “Учебники по истории Беларуси переписали (фото)” August 21, 2009. Available: http://charter97.org/ru/news/2009/8/21/21280/

European External Action Service, www.eeac.europa.eu. EU Around the Globe, Belarus. Available: http://eeas.europa.eu/belarus/index_en.htm

From the record of Alyaksandr Lukashenka's Press Conference held on September 17, 2002. Tut.by News agency. Стенограмма пресс-конференции Президента Республики Беларусь А.Г.Лукашенко 17 сентября 2002г. http://news.tut.by/society/18153.html 
Historical and Cultural Complex "Stalin line" www.stalin-line.by. Available: http://www.stalinline.by/140114.shtml

Informational and Analytical portal "Nasledie," "Распад СССР в школьных учебниках: России, Украины, Беларуси, Латвии, Киргизии, Таджикистане, Кахазстана, Армении, Грузии, Молдавии и Германии.” August 20, 2013. Available: http://nasledie.ru/?q=node/2314

Medieval History and Military Club the Duke's Order (Княжы Гуф). Available: http://belknight.com/club/index.php

News Agency Regnum, «Становление поневоле»: проблема формирования белорусской нации в школьном курсе истории Белорусии, January 14, 2014. Available: http://www.regnum.ru/news/polit/1754078.html

Russian BBC Service, “Белоруссия: как пишут учебники истории,” November 6, 2013. Available: http://www.bbc.co.uk/russian/international/2013/11/131028 history textbook belarus.shtml

Preiherman, Yauheni. Lukashenka's State of The Nation Address: Top 5 Messages, April 24, 2014. News Agency. www.belarusdigest.com Available: http://belarusdigest.com/story/lukashenkasstate-nation-address-top-5-messages-17618

Stary Olsa, the medieval Belarusian music band. Official webpage. Available: http://staryolsa.com/rus/dasje.html.

The Lithuanian Tribune, News and Views from Lithuania. "Belarusian rewriting history - do you think you're the Lithuanians?" September 27, 2013. Available: http://www.lithuaniatribune.com/52087/belarusians-rewriting-history-do-you-think-youre-thelithuanians-201352087/

The Human Rights Watch www.hrw.org. "Reviving Soviet History." Republic of Belarus: Violations of Academic Freedom, Vol. $11 \quad$ No.7 $\quad$ (D) (July 1999). Available: http://www.hrw.org/reports/1999/belarus/Belrus99-05.htm

The official webpage of the Litvin movement, available: www.litvania.org

Белорусский Республиканский Союз Молодёжи БРСМ, www.brsm.by. Культурно-массовые мероприятия, «За любимую Беларусь». Available: http://www.brsm.by/ru/proekt/Kultmasmeropr/za lub bel

Міністэрства культуры Рэспублікі Беларусь, www.kultura.by

Экскурсии по Беларуси, www.ekskursii.by, Гора Миндовга. Available: http://www.ekskursii.by/?exkursobj=2576

«Беларусам не нужен памятник Миндовгу» November 20, 2012. Беларусский Партизан, www.belaruspartisan.org. Available: http://www.belaruspartisan.org/life/223395/ 
«В Гродно на месте снесённой 52 года назад Фары Витовта появится памятный знак» December 2, 2013. Блог Гродно s13, www.s13.ru. Available: http://s13.ru/archives/70569

«Глобус Беларуси», Архитектурные и иные достопримечательности Беларуси. Available: http://www.globus.tut.by/index.htm

«Культуролог Чернявская: Путь от «тутэйшых» к нации белорусы уже прошли» March 23, 2010. Белорусский партизан, $\quad$ www.belaruspartisan.org. http://www.belaruspartisan.org/life/158526/

«Лукашисты предлагают вычеркнуть ВКЛ из истории Беларуси» March 15, 2002, Хартыя'97, www.charter 97.org. Available: http://charter97.org/ru/news/2012/3/15/49337/

«Рыцары Вялікага Княства» ў Менску, February 20, 2008. Наша Нiва, www.nn.by. Available: http://nn.by/?c=ar\&i=15178 